\title{
Meiofauna assemblages of the Condor Seamount (North-East Atlantic Ocean) and adjacent deep-sea sediments
}

\author{
Daniela Zeppilli ${ }^{a, b, c, ~ *}$, Lucia Bongiorni ${ }^{a, d}$, Antonio Cattaneo $^{e}$, Roberto Danovaro ${ }^{f}$ \\ Ricardo Serrão Santos ${ }^{\mathrm{a}, \mathrm{g}}$
}

\footnotetext{
a Centre of IMAR of the University of the Azores \& LARSyS Associated Laboratory, PT-9901-862 Horta, Azores, Portugal

b Observatoire de I'IUEM, Séries Faune Flore, UMS3113, Institut Universitaire Européen de la Mer, Place Copernic 29280 Plouzané, France

${ }^{c}$ IFREMER, Centre Brest, REM/EEP, Institut Carnot Ifremer-EDROME, ZI de la pointe du diable, CS10070, F29280 Plouzané, France

${ }^{d}$ Institute of Marine Sciences - National Research Council (ISMAR-CNR), Castello 2437/F, 30122 Venezia, Italy

e IFREMER, Centre Brest, Géosciences Marines, Laboratoire Environnements Sédimentaires, Ifremer, F-29280 Plouzané, France

${ }^{f}$ Department of Life and Environmental Sciences, Polytechnic University of Marche, Via Brecce Bianche, 60131 Ancona, Italy

${ }^{9}$ Department of Ocenography and Fisheries of the University of the Azores, PT-9901-862 Horta, Azores, Portugal

*: Corresponding author : Daniela Zeppilli, tel.: +3329822 4305 ; fax: +33298224757 ;

email address : Daniela.Zeppilli@ifremer.fr
}

\begin{abstract}
:
Seamounts are currently considered hotspots of biodiversity and biomass for macro- and megabenthic taxa, but knowledge of meiofauna is still limited. Studies have revealed the existence of highly diverse meiofauna assemblages; however most data are mainly qualitative or focused only on specific groups, thus preventing comparisons among seamounts and with other deep-sea areas. This study, conducted on Condor Seamount (Azores, North-East Atlantic Ocean), describes variation in abundance, biomass, community structure and biodiversity of benthic meiofauna from five sites located on the Condor Seamount: and one site away from the seamount. While the summit of the seamount hosted the highest alpha biodiversity, the flanks and the bases showed a rich meiofauna assemblage in terms of abundance and biomass. The observed marked differences in grain size composition of sediments reflected the oceanographic conditions impacting different sectors of the Condor seamount, and could play an important role in the spatial distribution of different meiofaunal taxa. Trophic conditions (biochemical composition of organic matter) explained $78 \%$ of the variability in the meiofauna biomass pattern while sediment grain influenced the vertical distribution of meiofauna and only partially explained meiofaunal taxa composition. This study provides a further advancement in the knowledge of meiofaunal communities of seamounts. Only a deeper understanding of the whole benthic communities (including meiofauna) will allow to elaborate effective management and conservation tools for seamount ecosystems.
\end{abstract}

Keywords : Condor Seamount ; Meiofauna ; Biodiversity ; Deep-sea sediments ; Azores 


\section{Introduction}

Seamounts are topographic elevations of the deep-sea seafloor (Pitcher et al., 2007; Wessel et al., 2010; Yesson et al., 2011). Several seamounts contribute to create peculiar hydrological conditions, such as enhanced current flow, eddies, up- and down welling and closed retention cells (i.e. Taylor caps; White et al., 2007), which can provide enhanced food resources to benthic fauna (Piepenburg and Müller, 2004). Because of these characteristics, seamounts are considered hotspots of biodiversity and biomass of several macro- and megabenthic taxa (Samadi et al., 2006; Samadi et al., 2007; Rowden et al., 2010; Clark et al., 2010; Sautya et al., 2011; Tracey et al., 2011).

Despite an increasing knowledge on seamounts and their associated biodiversity, our knowledge about meiofaunal component is still limited (McClain, 2007; Vanreusel et al., 2010). Among the ca. 232 seamounts sampled world-wide, only 8 have been sampled for meiofauna (George, 2013). Due to difficulties encountered in seamounts sampling and the use of different sampling devices, meiofaunal studies remain mainly qualitative or focused only on specific taxa, thus preventing comparisons among seamounts and between seamounts and other deep-sea habitats (see George, 2013). The most detailed investigations on the biodiversity, community composition and distribution of meiofauna on seamounts have been carried out in the North Atlantic Ocean and in particular in the Great Meteor, Sedlo and Seine Seamounts (George, 2013 and references therein). Some of these studies have revealed the existence of highly diverse meiofauna assemblages living in sediments of seamounts when compared to those typical of the deep sea (Gad and Schminke, 2004) with several species and genera new to science (George, 2004, 2006; Gad, 2004a, 2004b). Others studies have suggested seamounts as potential areas of endemism 
also for meiofaunal species and as "stepping stone" for large-scale dispersal of some meiofaunal taxa such as nematodes and copepods (George and Schminke, 2002; George, 2004; Gad, 2009, Piepenburg and Müller, 2004; Mironov and Krylova, 2006).

The present study aims to compare meiofaunal assemblages in five sites on the Condor Seamount (Azores, North-East Atlantic Ocean) and in a nearby open slope site. We investigated variations in abundance, community structure, and biodiversity of benthic meiofauna and its relationship with environmental variables (including sediment grain size and available food resources) in order to answer to the following questions:

i) Is there a difference between the meiofaunal biodiversity (expressed as richness of higher taxa) between seamount and open slope sites?

(ii) Is there a difference in meiofaunal biodiversity and assemblage structure among different seamount areas (summit, flanks and bases) and between the northern and southern slope?

(iii) Is the seamount summit a hotspot of meiofaunal abundance, biomass and diversity?

\section{Material and methods}

\subsection{Study sites and samples collection}

The main geomorphologic characteristics of the Condor Seamount are described in Tempera et al. (2012). Condor is a linear volcano located in the Azores (northeast Atlantic), $17 \mathrm{~km}$ to the southwest of Fayal Island. It is $39 \mathrm{~km}$ long, $23 \mathrm{~km}$ wide, and extends from more than $1800 \mathrm{~m}$ to $185 \mathrm{~m}$ water depth (Tempera et al., 2012; Tempera et al, this issue). 
This seamount has a flat summit characterised by the presence of large rocky outcrops, boulders, gravels, and coarse bioclastic deposits and steep slopes mainly characterized by unconsolidated sediments (Tempera et al., 2012).

Condor Seamount is impacted by a dominant background oceanographic flow directed NW-SE and hosts a multi-scale dynamic oceanographic conditions including enhanced mixing, upwelling-downwelling processes and closed circulation structures over the seamount, that make it distinct from the surrounding ocean (Bashmachnikov et al., submitted this issue; Tempera et al., 2012). Habitats of conservation importance, such as deep-water coral gardens and deep-sea sponge aggregations have been documented on the Condor Seamount (Tempera et al., 2012; Braga-Henriques et al., in press this issue).

Sediment samples were collected between 26 and 31 July 2010 onboard of the R.V. Noruega, in a total of five sites on the seamount itself: summit (site 9, 206 m), flank North (site 2, $1290 \mathrm{~m}$ ), flank South (site 4, $1006 \mathrm{~m}$ ), base North (site 3, $1687 \mathrm{~m}$ ) and base South (site 6, $1719 \mathrm{~m}$ ), and in an external, far field site situated $20 \mathrm{~km}$ to the southwest (site 8, 1900 m, Table 1 and Fig. 1). At all sites five sediment cores were retrieved from two independent deployments of an interface multicorer (Midicorer Mark II 400) equipped with four core tubes (100 mm diameter), which allowed undisturbed and sealed sediment samples to be obtained (Danovaro, 2010). For each site, four sediment cores (two from deployment 1 and two from deployment 2) were carefully sub-sampled for meiofaunal by inserting PVC liners (2.8 cm diameter). The four sub-cores were successively thin-sliced $(0-1,1-3,3-5,5-10,10-15 \mathrm{~cm})$ for vertical distribution analyses, with exception of the station 9 (summit) where the maximum corer penetration was $10 \mathrm{~cm}(0-1,1-3,3-5,5-10$ $\mathrm{cm}$ slices). Additional sediment sub-samples obtained from both deployments were 
immediately stored at $-20^{\circ} \mathrm{C}$ for further biochemical analyses (Bongiorni et al., this issue). All of the sub-samples for the meiofaunal analyses were preserved in buffered $4 \%$ formalin solution and stained with Rose Bengal.

For grain size analyses one sediment core for each sampling site was sliced into 5 layers: $0-1,1-3,3-5,5-10 \mathrm{~cm}$ and $10-15 \mathrm{~cm}$, with exception of the station 9 where the maximum corer penetration was $10 \mathrm{~cm}(0-1,1-3,3-5,5-10 \mathrm{~cm}$ slices $)$ and refrigerated until analyses.

\subsection{Grain size analyses}

A total of twenty-nine sediment sub-samples were obtained from all the sampling sites and from intervals 0-1, 1-3, 3-5, 5-10, 10-15 cm (except for site 9, seamount summit, where the 10-15 cm layer was not available). Sub-samples from core 9 were dried overnight in an oven at $80^{\circ} \mathrm{C}$, weighted and sieved with a Fritsch 'analysette $3 \mathrm{PRO}$ ' shaker (cycles of $0.2 \mathrm{~mm}$ amplitude for 60 seconds). Each fraction (from 4 to $0.063 \mathrm{~mm}$ ) was then weighted separately. Sub-samples from the other sites were dried in an oven overnight at $80^{\circ} \mathrm{C}$, weighted and wet sieved to extract the fraction $>2 \mathrm{~mm}$, which was dried and weighted. The fraction $<2 \mathrm{~mm}$ was sub-sampled after gently stirring by hand to homogenise it. The sub-sampled fraction was disaggregated with a Retsch MM200 mixer mill at 17 cycles per second for 4 minutes and analysed with a Coulter LS200 laser microgranulometer at Ifremer. We composed weights percent from sieve and Coulter Counter percent values of each virtual sieve.

\subsection{Meiofaunal abundance, biomass and community structure}


Sediment samples were pre-sieved through a $1000-\mu \mathrm{m}$-mesh net, and the organisms were retained on a $20-\mu \mathrm{m}$-mesh net. This latter fraction was resuspended and processed according to the protocol reported by Danovaro (2010). All of the meiofauna organisms were counted and classified per taxon under a stereomicroscope as reported by Danovaro (2010). Hard-bodied organisms were identified under the stereomicroscope, while softbodied organisms were mounted on slides and viewed at 1000X magnification. The abundance of the meiofauna was reported as individuals $\times 10 \mathrm{~cm}^{2}$. The biovolumes of all taxa (except for nematodes) were measured at the Olympus SZX16 stereo zoom microscope (magnification 230x) for all of the specimens encountered. Nematodes were picked up, mounted on slides and measured with ocular micrometer using a compound microscope. The body volumes of all taxa were derived from measurements of their body lengths $(\mathrm{L}$, in $\mathrm{mm})$ and widths $(\mathrm{W}$, in $\mathrm{mm})$, using the formula $\mathrm{V}=\mathrm{Lx} \mathrm{W}^{2} \times \mathrm{C}$, where $\mathrm{C}$ is the approximate conversion factor for each meiofaunal taxon. This later formula is applicable to organisms characterized by an irregular shape (i.e., copepods, Danovaro, 2010). To obtain the biomass [ $\mu \mathrm{g}$ dry weight (DW): $\mu \mathrm{g}$ wet weight (WW) ratio, 0.25 ], each body volume was multiplied by an average density $\left(1.13 \mathrm{~g} \mathrm{~cm}^{-3}\right)$. The nematode biomass was calculated from the biovolume, which was estimated from all specimens per replicate using the Andrassy formula $\left(\mathrm{V}=\mathrm{L} \mathrm{X} \mathrm{W} \mathrm{W}^{2} \mathrm{X} 0.063 \times 10^{-5}\right.$, with body length, $\mathrm{L}$, and width, $\mathrm{W}$, expressed in $\mu \mathrm{m}$ ). Carbon content was assumed to be $40 \%$ of DW (Feller and Warwick, 1988). Total meiofaunal abundance and biomass were calculated by summing up all sediment layers of each core. Vertical profiles within each site were studied in the depth layers $0-1,1-3,3-5,5-10$ and $10-15 \mathrm{~cm}$ (with exception of the station 9 where the maximum penetration was $10 \mathrm{~cm}$ ). 


\subsection{Meiofaunal biodiversity}

Meiofaunal higher taxa richness (HT), the turnover diversity ( $\beta)$, and the local $(\alpha)$ and regional $(\gamma)$ diversities were calculated using the community analysis PRIMER v6 software (Clarke and Gorley, 2006). The $\alpha$ and $\gamma$ diversities are inventory diversity measures that provide information on the diversity in an area at small (i.e., a single core) and large spatial scales (i.e., different habitats). The $ß$ diversity provides indications of any change in community composition and can be expressed as percentages of dissimilarity (e.g. based on a Bray-Curtis similarity matrix; Gray, 2000). The SIMPER analysis was used to determine the contributions of each species to the average Bray-Curtis dissimilarity (Clarke and Warwick, 2001). This analysis of dissimilarities was based on a fourth root transformation matrix. The $\gamma$ diversity was calculated as the total biodiversity at a regional level (the area comprising the Condor seamount and surrounding sediments).

\subsection{Statistical analyses}

Data on sediment grain size were analyzed using the GRADISTAT v 8.0 software (Blott and Pye, 2001). Mean, sorting, skewness, kurtosis, and a range of cumulative percentile values $\left(D_{10}, D_{50}, D_{90}\right)$ were calculated arithmetically and geometrically (in metric units) following Folk and Ward (1957). Skewness measures the symmetry of particle distribution, while Kurtosis expresses the ratio of the sorting in the extremes of the distribution compared with the sorting in the central part and as such is a sensitive and valuable test of the normality of a distribution. In the statistical treatment of grain size data we followed the approach of Folk and Ward (1957) which is most appropriate when data 
are non-normally distributed as it is the case of polymodal sediments from the Condor Seamount.

Differences in meiofaunal abundance, biomass and biodiversity among seamount sites, between seamount and far field sites were tested by a one-way analysis of variance (ANOVA). The GMAV (1997) statistical package (University of Sydney, Australia) was used to perform the ANOVA. Before the ANOVA, the homogeneity of variances was tested using the Cochran test and data were square root transformed whenever necessary The Student Newman-Keuls (SNK) test was used for post hoc comparisons.

The PRIMER6 software (Plymouth Marine Laboratory, UK; Clarke, 1993) was used to determine the Bray-Curtis similarities among all of the sampling sites (with data fourth root transformed).The analysis of the similarities (ANOSIM) and the similarity percentages (SIMPER) were performed using the PRIMER6 software (permutation number, 4999).

To evaluate the relationship between meiofaunal abundance, biomass and species composition and environmental variables (i.e. sediment grain size as indicator of habitat heterogeneity, and trophic characteristics of sedimentary organic matter as proxy of food availability for benthic consumers) we conducted a nonparametric multivariate multiple regression analysis (DISTML: distance-based linear model) using the PERMANOVA+ addon package for PRIMER 6 software (McArdle and Anderson, 2001; Anderson et al., 2008). For abundance and biomass, the Euclidean distance was used as resemblance measure, whereas for species composition the analysis was based on Bray-Curtis dissimilarities. The step-wise selection was carried out and the adjusted $\mathrm{R}^{2}$ was selected as criterion to enable the fitting of the best explanatory environmental variables in the model (Anderson et al., 2008). Only variables (meiofauna variables, sediment parameters and trophic resources) 
related to $0-1 \mathrm{~cm}$ sediment layer were tested. Quantity and quality of organic matter in sediments of the Condor Seamount and the far field site corresponding to sampling sites of this study are detailed in Bongiorni et al. (submitted this issue). Concentrations of phaeopigments and biopolymeric organic carbon (as sum of protein, carbohydrate and lipid carbon equivalents, Fabiano et al., 1995) were used as indicators of the amount of trophic resources while the proteins to carbohydrate concentrations ratio (PRT:CHO) was used as indicators of their quality. Percentage of gravel, sand, silt and clay in the sediment were used as indicator of habitat heterogeneity (Pape et al., 2013). For the grain size variables, the same values of each parameters was assigned to all 4 faunal cores from the same site, while in the case of the trophic variables, 4 independent values of each parameter were available. Water depth was used as additional environmental constraint.

\section{Results}

\subsection{Sediment grain size}

Sediment characteristics of the investigated sites are reported in Table 2 and in Fig. 2. The Condor summit showed a different sediment grain composition compared to the other sites, being composed by a gravelly bioclastic sand rich in angular shell fragments (pteropods, gastropods, echinoids, bivalves), rounded pumex clasts, polished lava pebbles and planktonic foraminifera shells. The other sites showed in general poorly sorted sediment dominated by sand on the flanks and by silt at the base of the seamount. The northern flank and base displayed coarser sediments than their southern counterparts. Sediment grain size at the far field site was comparable to that at the southern base. Four 
out of six sample sites showed an increase in grain size from the bottom to the top of the sediment core (sites 2, 6, 8, 9; Fig. 2).

\subsection{Meiofaunal abundance, biomass and assemblages composition}

Meiofaunal abundance and biomass differed significantly among sites (Fig. 3 and 4). Post hoc SNK test showed that meiofauna abundance was significantly higher only in sediments of the southern flank $\left(365.5 \pm 153.9\right.$ ind $\left.10 \mathrm{~cm}^{-2}\right)$ compared to the sediments of the far field site $\left(179.1 \pm 40.5\right.$ ind $10 \mathrm{~cm}^{-2}, \mathrm{P}<0.05$; Table 3; Fig. 3). Total biomass was significantly higher at the base North of the seamount than at the base South $(111.4 \pm 19.1$ and $52.4 \pm 21.8 \mu \mathrm{gC} 10 \mathrm{~cm}^{-2}$, respectively, $\mathrm{P}<0.01$; Fig. 4) and both these sites displayed the higher biomass compared to all the others $(\mathrm{P}<0.001$; Table 3$)$. Meiofaunal biomass was ten times less at the far field site than at the Condor northern base $(13.3 \pm 6.0 \mu \mathrm{gC} 10$ $\mathrm{cm}^{-2}, \mathrm{P}<0.001 ;$ Fig. 4).

Meiofaunal abundance was generally concentrated in the top first centimeter-layer of the sediment cores and decresed with depth along the vertical profiles (Fig. 5), except for the summit, where distribution was homogeneous among layers. A similar vertical pattern was observed for meiofaunal biomass with the exception of the base North, where biomass was mainly concentrated in the $1-3 \mathrm{~cm}$ layer (Fig. 6). On the Condor summit meiofaunal biomass was evenly distributed among sediment layers (Fig. 6). Raw data of biomass and vertical profile of abundance and biomass for all stations, samples and meiofaunal groups are shown in Appendix I, II and III, respectively.

Nematodes dominated meiofaunal abundance at all sites (85-93\%, Fig. 7). Nematodes, copepods, polychaetes, loriciferans and acari were recorded in all investigated 
sites. Tardigrades were encountered in all sampling sites except in the southern slope (flank and base). Ostracods were encountered exclusively in the summit and in the southern slope (flank and base). Kinorhynchs were present only in the southern slope of the Condor (flank and base). Isopods were encountered exclusively in the summit and in the base South while cumaceans only in the flank North and in the far field site. A schematic representation of the spatial distribution of tardigrades, ostracods, kinorhynchs, isopods and cumaceans is reported in Figure 8. Tanaidaceans, gastropods, echiuroids and bivalves were encountered exclusively in only one of the sites sampled, i.e. in the flank North, in the summit, in the base South and in the flank South, respectively.

The highest taxa richness was observed in the seamount summit (10 taxa), in the two flanks we encountered 8 taxa, in the bases the number of higher taxa ranged from 6 to 9 taxa (base North and South, respectively), whereas in the far field site 8 taxa were recorded (Fig. 9). The $\alpha$-diversity (measured as total number of higher taxa) was highest at the seamount summit (10 taxa) and lowest in the base North (6 taxa, Fig. 9). The SIMPER and ANOSIM analyses (Table 4) revealed the presence of significant differences in the meiofaunal composition only between the summit and the base North $(\mathrm{P}<0.05 ; \mathrm{R}=0.333)$.

\section{3 Relationships between meiofaunal distribution and environmental characteristics}

Water depth explained $30 \%$ of the variation in meiofaunal abundance $(\mathrm{P}<0.01$; Table 5). Trophic variables together explained $78 \%$ of variability in meiofaunal biomass (P $<0.001)$, while only $10 \%$ of biomass variance was explained by water depth $(\mathrm{P}<0.01)$. Sediment grain size, in particular the percentage of gravel, explained $12 \%$ of the variability of the meiofauna taxa composition (Table 5). 


\section{Discussion}

In this study, results of sediment grain-size distribution on the Condor Seamount supported the occurrence of strong water mixing. The summit of the Condor resulted to be characterized by coarse grained sediments, in accordance to Caetano et al. (2013, this issue), indicating an area swept by bottom currents where sediments are winnowed and reworked. Similar conclusions were also reported by Bongiorni et al. (submitted this issue) who found low level of sediment organic matter on the seamount summit when compared to the other sites. The depth-related gradient in sediment grain-size was evident at depths $<1500 \mathrm{~m}$ as observed previously at regional scale by Dennielou (1997) and Dennielou et al. (1999). Moreover, the presence of coarser sediment in the northern slope of the Condor compared to the southern side could be linked to the effects of horizontal asymmetries in the flow field around the seamount (Holloway and Merrifield, 1999; Munroe and Lamb, 2005). Similar north-south slopes differences on the Condor were also observed in term of sediment organic matter quality, measured as proteins to carbohydrate ratio and contribution of proteins to biopolymeric carbon (Bongiorni et al., submitted this issue), and explained as result of the influence of the dominant oceanographic flow impacting the seamount from the North.

Meiofaunal abundances reported on the Condor are consistent with available information from other sites of the North Atlantic Ocean, at similar depths (Flach et al., 2002; Raes and Vanreusel, 2005; Bianchelli et al., 2010). Studies on seamounts meiofauna are extremely scarce and in most cases are only qualitative (George, 2013); therefore a direct comparison of data from different seamounts is difficult. In this study, higher values 
of meiofaunal abundance and biomass were found at the southern flank and at the base of the Condor Seamount when compared to the far field site (Fig. 3 and 4). Similar results were found at the Josephine Seamount (Atlantic Ocean), where higher meiofaunal abundances were found at the seamount summit rather than in a control site external to the seamount (Levin and Gooday, 2003). However our data are in contrast with a previous investigation conducted in sediments surrounding two Mediterranean seamounts (Pusceddu et al., 2009). These authors showed a meiofaunal abundance and biomass generally lower in sediment close to the Palinuro and Marsili Seamounts than in reference deep-sea sediments, and directly related with a lower level of food resources. The DISTLM analyses revealed that variations in meiofaunal abundance on the Condor Seamount were mainly correlated with water depth. Food availability (trophic conditions expressed both in terms of quantity and quality of the sediment organic matter) explained a significant portion of variation in meiofaunal biomass. Physical factors such as local hydrodynamic conditions and changes in sediment transport induced by seamount topography may influence sediment texture (Turnewitsch et al., 2004), sediment organic matter content (Consalvey et al., 2010), dispersal, entrapment and retention of larvae (Lavelle and Mohn, 2010). These factors together with depth can influence biodiversity and shape benthic community structure (Levin and Thomas, 1989; Consalvey et al., 2010). However the predominance of one factor over the others may depend on local conditions and thus vary with seamount geographical location.

Direct adaptation to sediments is one of a principal cause of variation in the sediment-dwelling fauna (Snelgrove and Butman, 1994). Although several coastal studies showed that meiofaunal community structure is intimately related to sediment 
architecture (Steyaert et al., 2003; Giere, 2009 and references therein), information about the relationship between meiofauna and sediment characteristics in the deep sea, and in particularly in seamounts, are scarce. Several studies have shown that the penetration of meiofauna organisms into deep-sea sediments is governed by both the oxygenation of sediments (Shirayama, 1984) and food availability (Lambshead et al., 1995; Vanreusel et al., 1995). On the Condor summit the meiofauna resulted to penetrate down to the deepest layers (Fig. 5), while in all other sites the meiofauna showed a superficial distribution. This can be attributed to the coarse grain size and large intergranular voids of the summit sediments, allowing nematodes and copepods to penetrate into the sub-superficial sediments.

While several scientists are debating about the assumption that seamount are hotspots of biodiversity, quantitative studies comparing benthic diversity, per unit of area, on and off seamounts in similar substrate, are rare (McClain, 2007; Rowden et al., 2010). The number of meiofauna higher taxa identified on the Condor Seamount (6-10, Fig. 9) was lower than those reported on some Atlantic seamounts (1-25, George, 2013), but higher than those from seamounts of the Pacific Ocean (4-5, George, 2013). Similarly to findings related to the Great Meteor Seamount (Heinz et al., 2004), the number of higher taxa on the Condor did not vary significantly among sites. Beta diversity, which reflects turnover of meiofauna across the seamount and between the seamount sites and the far field, was always less that $30 \%$ and significant only when comparing the summit with the base North. The DISTLM analyses showed that sediment characteristics only explained $12 \%$ of the variation in meiofaunal community structure. Most of the variation in meiofaunal 
community composition (88\%) was not explained by the tested environmental variables, thus suggesting that other environmental or biological factors might be responsible.

\section{Conclusion and final remarks}

The Condor Seamount hosted a rich and diverse meiofaunal assemblage. The analysis of meiofauna in distinct physiographic sites of the Condor Seamount (its summit, the north and south flanks, the north and south bases) allowed answering to the following questions:

i) Is there a difference between the meiofaunal biodiversity (expressed as richness of higher taxa) associated to a seamount and the one of the adjacent deep-sea sediments?

Although the highest number of taxa was recorded in the Condor summit, no significant difference in community structure was observed between the seamount and the surrounding far field site.

(ii) Is there a difference in meiofaunal biodiversity and assemblage structure among different seamount areas (summit, flanks and bases) and between the northern and southern slope?

Although there were no significant differences in meiofaunal diversity and community structure among seamount sites, the Condor flanks and bases revealed a rich meiofauna assemblage (in term of abundance and biomass) when compared to the other sites. No significant differences were found between the northern and southern slope. However the asymmetric N-S oceanographic condition observed on the Condor and the associated sediment mixing and grain size composition could likely play a role in the spatial distribution of meiofaunal taxa. 
(iii) Is the summit a hotspot of meiofaunal abundance, biomass and diversity?

The Condor summit hosted the highest alpha biodiversity, however, the flanks and the bases showed a rich meiofauna assemblage in terms of abundance and biomass. It is evident that not only the summit can support a rich meiofaunal community in terms of standing stocks and diversity and this finding should be considered in future studies on meiofauna distribution in seamounts.

Seamounts have been described as oases of productivity, hotspots of biodiversity and areas with high potential for endemic species (Richer De Forges et al., 2000; Rowden et al., 2010). Because available data on meiofaunal communities are scarce, such theories for meiobenthic organisms remain untested. Further studies on meiofauna from seamounts adjacent islands, the surrounding deep sea and continental areas are urgently needed in order to unravel meiofaunal distribution patterns and the possible role of seamount as stepping stones for dispersion and colonization (Hubbs, 1959; Santos et al., 1995; Gad and Schminke, 2004; Shank, 2010). Seamounts are unique features of the deep-sea which are subjected to several threats such as overfishing and bottom trawling, and represent areas of potential interests for deep-sea mineral and metal extraction (Probert et al., 2007; Clark et al., 2010; Clark and Tittensor, 2010; Hein et al., 2010; Muinos et al., 2013). A better knowledge of the whole seamounts benthic communities (including meiofauna) will provide the scientific support to predict changes in the biology and ecology of seamount assemblages in response to present and future threats and to elaborate effective management and conservation tools. 


\section{Acknowledgments}

This work was funded by the Fundação para a Ciência e Tecnologia, Portugal (FCT Project BIOMOUNT, PTDC/MAR/105486/2008. COMPETE funds). The authors are indebted to the CONDOR project (Observatory for long term study and monitoring of Azorean ecosystem, EEA Grants- PT0040/2008, Iceland, Liechtenstein). We are particular grateful to Dr Gui Menezes, Dr Eva Giacomello and Ricardo Medeiros. We thank captain and crew of the RV Noruega, and cruise participants from IMAR-DOP/University of the Azores, IPIMAR, ISMAR-CNR (Italy) for their help during sediment sampling. The authors thank B. Dennielou and F. Tempera for useful discussion about Azorean deep-sea sediments. IMARDOP/UAc is Research and Development Unit \#531 and LARSyS-Associated Laboratory funded by FCT (OE, FEDER, POCI2001, FSE, COMPETE) and by the Azores Directorate for Science, Technology and Communications (DRCTC). DZ was partly supported by a grant from the French government through Agence Nationale de la Recherche (ANR) under the "Investissements d'Avenir" programme, reference ANR-10-LABX-19-0. LB and RD were supported by the RITMARE flagship project - 2012-2016 supported by MIUR and coordinated by CNR, Italy.

\section{References}

Anderson, M.J., Gorley, R.N., Clarke, K.R., 2008. PERMANOVA+ for PRIMER: guide to software and statistical methods. PRIMER-E Ltd,, Plymouth.

Bashmachnikov, I., Loureiro, C., Martins, A. Topographically induced circulation patterns and mixing over Condor seamount. Deep Sea Res. II, submitted this issue. 
Bianchelli, S., Gambi, C., Zeppilli, D., Danovaro, R., 2010. Metazoan meiofauna in deep-sea canyons and adjacent open slopes: a large-scale comparison with focus on the rare taxa. Deep-Sea Res Part I 57, 420-433.

Blott, S.J. and Pye, K., 2001. GRADISTAT: a grain size distribution and statistics package for the analysis of unconsolidated sediments. Earth Surf. Proc. Land. 26, 1237-1248.

Bongiorni, L., Ravara, A., Paretti, P., Santos, R.S., Rodrigues, C.F., Amaro, T., Cunha, M.R. Organic matter composition and macrofaunal diversity in sediments of the Condor seamount (Azores, NE Atlantic). Deep Sea Res. II, submitted this issue.

Braga-Henriques, A., Porteiro, F.M., Ribeiro, P.A., de Matos, V., Sampaio, Í., Ocaña Vicente O., Santos, R.S., Diversity, distribution and spatial structure of the cold-water coral fauna of the Azores (NE Atlantic). Biogeosciences, in press.

Caetano M., Vale C., Anes B., Raimundo J., Drago T., Schimdt S., Nogueira M., Oliveira A., Prego R., 2013. The Condor seamount at Mid-Atlantic Ridge as a supplementary source of trace and rare earth elements to the sediments. Deep-Sea Res., this issue [http://dx.doi.org/10.1016/j.dsr2.2013.01.009i].

Clark, M.R., Tittensor, D.P., 2010. An index to assess the risk to stony corals from bottom trawling to seamounts. Mar. Ecol. 31(1), 200-211.

Clark, M.R., Rowden, A., Schlacher, T., Williams, A., Consalvey, M., Stocks, K. I., Rogers, A.D., O'Hara, T.D., White, M., Shank, T.M., Hall-Spencer, J.M., 2010. The ecology of seamounts: structure, function, and human impacts. Ann. Rev. Mar. Sci. 2, 253-278.

Clarke, K.R., 1993. Non parametric multivariate analyses of changes in community structure. Aust. J. Ecol. 18, 117-143.

Clarke, K.R., Gorley, R.N., 2006. PRIMER v6: User Manual/Tutorial. PRIMER-E, Plymouth. 
Clarke, K.R., Warwick, R.M., 2001. Change in Marine Communities: An Approach to Statistical Analysis and Interpretation. PRIMER-E Ltd., Plymouth, UK.

Consalvey, M., Clark, M.R., Rowden, A.A.,, Stocks, K.I., 2010. Life on Seamounts, in: McIntyre, A.D. (Eds.), Life in the World's Oceans: Diversity, Distribution and Abundance. Blackwell Publishing Ltd, Oxford, pp. 123-138.

Danovaro, R., 2010. Methods for the study of deep-sea sediments their functioning and biodiversity. CRC Press, Boca Raton, FL.

Dennielou B., 1997. Dynamique sédimentaire sur le plateau des Açores pour les derniers 400 ka: Distribution, lithology, flux et processus. Implications paléocéanographiques. PhD thesis, Université de Bretagne Occidentale, Brest.

Dennielou, B., Auffret, G.A., Boelaert, A., Richter ,T., Garlan, T., Kerbrat, R., 1999. Contrôle exercé par la dorsale médio-Atlantique et le Gulf Stream sur la sedimentation quaternaire sur le plateau des Açores. (Control of the Mid-Atlantic ridge and the Gulf Stream on the Quaternary sedimentation on the Azores Plateau). CR Acad Sci Paris 328(12), 831-837.

Fabiano, M., Danovaro, R., Fraschetti, S. 1995. A three-year time series of elemental and biochemical composition of organic matter in subtidal sandy sediments of the Liguria Sea (northwestern Mediterranean). Cont. Shelf. Res. 15, 1453-1469.

Feller, R.J., Warwick, R.M., 1988. Energetics, in: Higgin, R.P., Thiel, H. (Eds.) Introduction to the study of meiofauna Smithsonian Institution Press, Washington, DC, pp. 181-196.

Flach, E., Muthumbi, A., Heip, C., 2002. Meiofauna and macrofauna community structure in relation to sediment composition at the Iberian margin compared to the Goban Spur (NE Atlantic). Progr. Oceanogr., 52, 433-457. 
Folk, R.L., Ward, W.C., 1957. Brazos River bar: a study in the significance of grain size parameters. J. Sediment. Petrol., 27, 3-26.

Gad, G., 2004a. The Loricifera fauna of the plateau of the Great Meteor Seamount. Arch. Fish. Mar. Res. 51, 9-29.

Gad, G., 2004b. Diversity and assumed origin of the Epsilonematidae (Nematoda) of the plateau of the Great Meteor Seamount. Arch. Fish. Mar. Res. 51, 30-42.

Gad, G., 2009. Colonisation and speciation on seamounts, evidence from Draconematidae (Nematoda) of the Great Meteor Seamount. Mar. Biodiv. 39, 57-69.

Gad, G., Schminke, H.K., 2004. How important are seamounts for the dispersal of interstitial meiofauna. Arch. Fish. Mar. Res. 51, 43-54.

George, K.H., 2004. Description of two new species of Bodinia, a new genus incertae sedis in Argestidae Por, 1986 (Copepoda, Harpacticoida), with reflections on argestid colonization of the Great Meteor Seamount plateau. Org. Divers. Evol. 4(4), 241-254.

George, K.H., 2006. New Ancorabolinae Sars, 1909 (Copepoda: Harpacticoida: Ancorabolidae) of the Atlantic Ocean. Description of Pseudechinopsyllus sindemarkae gen. et sp. nov. and Dorsiceratus ursulae sp. nov. from the Great Meteor Seamount, and redescription of D. octocornis Drzycimski, 1967, and D. triarticulatus Coull, 1973. Meiofauna Marina 15, 123-156.

George, K.H. 2013. Faunistic research on metazoan meiofauna from seamounts - a review. Meiofauna Marina 20, 1-32.

George, K.H., Schminke H.K. 2002. Harpacticoida (Crustacea, Copepoda) of the Great Meteor Seamount, with first conclusions as to the origin of the plateau fauna. Mar. Biol. 141, 887-895. 
Giere, O., 2009. Meiobenthology. The Microscopic Motile Fauna of Aquatic Sediments. Springer-Verlag, Berlin, Heidelberg.

Gray, J.S., 2000. The measurement of marine species diversity, with an application to the benthic fauna of the Norwegian continental shelf. J. Exp. Mar. Biol. Ecol. 250, 23-49.

Hein, J.R., Conrad, T.A, Staudigel, H., 2010. Seamount Mineral Deposits: A Source of Rare Metals for High-Technology Industries. Oceanography 23(1), 184-189.

Heinz, P., Ruepp, D., Hemleben, C., 2004. Benthic foraminifera assemblages at Great Meteor Seamount. Mar. Biol. 144, 985-988.

Holloway, P.E., Merrifield M.A., 1999. Internal tide generation by seamounts, ridges, and islands. J. Geophys. Res. 104, 25937-25951.

Hubbs, C.L., 1959. Initial discoveries of fish faunas on seamounts and offshore banks in the Eastern Pacific. Pacific Science 13, 311-316.

Lambshead, P.J.D., Ferrero, T.J., Wolff, G.A. 1995. Comparison of the vertical distribution of nematodes from two contrasting abyssal sites in the northeast Atlantic subject to different seasonal inputs of phytodetritus, Int. Rev. Gesamt. Hydrobiol. 80, 327-332.

Lavelle, J.W., Mohn. C., 2010. Motion, commotion, and biophysical connections at deep ocean seamounts. Oceanography 23(1):90-103.

Levin, L.A., Gooday, A., 2003. The deep Atlantic Ocean, in: Tyler, P.A. (Ed.), Ecosystems of the World: The Deep Sea. Elsiever, Amsterdam, pp. 111-178.

Levin, L.A., Thomas, C.L.,1989. The influence of hydrodynamic regime on infaunal assemblages inhabiting carbonate sediments on central Pacific seamounts. Deep Sea Res. 36(12), 1897-1915. 
McArdle, B.H., Anderson, M.J., 2001. Fitting multivariate models to community data: a comment on distance-based redundancy analysis. Ecology 82, 290-297.

McClain, G., 2007. Seamounts: identity crisis or split personality? J. Biogeogr. 34, 20012008.

Mironov, A.N., Krylova, E.N., 2006. Origin of the fauna of the Meteor Seamounts, north-east Atlantic, in: Mironov, A.N., Gebruk, A.V., Southward, A.J. (Eds.). Biogeography of the North Atlantic Seamounts. KMK Scientific Press, Moscow, pp. 22-57.

Muinos, S.B., Hein, J.R., Frank, M., Monteiro, J.H., Gaspar, L., Conrad, T., Pereira, H.G., Abrantes, F., 2013. Deep-sea Fe-Mn Crusts from the Northeast Atlantic Ocean: Composition and Resource Considerations. Mar. Georesour. Geotec. 31(1), 40-70.

Munroe, J.R., Lamb, K.G., 2005.Topographic amplitude dependence of internal wave generation by tidal forcing over idealized three-dimensional topography, J. Geophys. Res., 110(C02), 2156-2202.

Pape, E., Bezerra, T.N., Jones, D.O.B., Vanreusel, A., 2013. Unravelling the environmental drivers of deep-sea nematode biodiversity and its relation with carbon mineralisation along a longitudinal primary productivity gradient. Biogeosciences, 10, 3127-3143.

Piepenburg, D., Müller, B., 2004. Distribution of epibenthic communities on the Great Meteor Seamount (NE Atlantic) mirrors pelagic processes. Arch. Fish. Mar. Res. 51, $55-70$.

Pitcher, T., Morato, T., Hart, P.J.B., Clark, M.R., Haggan, N., Santos, R.S. editors, 2007. Seamounts: Ecology, Fisheries and Conservation. Blackwell Fisheries and Aquatic Resources Series. 
Probert, P. K., Christiansen, S., Gjerde, K.M., Gubbay, S., Santos, R.S., 2007. Management and conservation of seamounts, in: Pitcher, T. J., Morato, T., Hart, P. J.B., Clark, M.R., Haggan, N., Santos, R.S. (Eds.), Seamounts: Ecology, Fisheries and Conservation. Blackwell Publishing, Oxford, UK. pp. 442-475.

Pusceddu, A., Gambi, C., Zeppilli, D., Bianchelli, S., Danovaro, R., 2009. Organic matter composition, meiofauna and nematode biodiversity in deep-sea sediments surrounding two seamounts. Deep-Sea Res. II 56, 755-762.

Raes, M., Vanreusel, A., 2005. The metazoan meiofauna associated with a cold-water coral degradation zone in the Porcupine Seabight (NE Atlantic). In: Freiwald, A., Roberts, J.M. (Eds.), Cold-water Corals and Ecosystems. Springer, Berlin, Heidelberg, pp. 821847

Richer de Forges, B.R., Koslow, J.A., Poore, G.C.B., 2000. Diversity and endemism of the benthic seamount fauna in the southwest Pacific. Nature 405, 944-947.

Rowden, A.A., Schlacher, T.A., Williams, A., Clark, M.R., Stewart, R., Althaus, F., Bowden, D.A., Consalvey, M., Robinson, W., Dowdney J., (2010) A test of the seamount oasis hypothesis: seamounts support higher epibenthic megafaunal biomass than adjacent slopes. Mar. Ecol. 31: 95-106.

Samadi, S., Bottan, L., Macpherson, E., Richer De Forges, B. Boisselier, M.C., 2006. Seamount endemism questioned by the geographical distribution and population genetic structure of marine invertebrates. Mar. Biol. 149, 1463-1475.

Samadi, S., Schlacher, T.A., Richer de Forges, B., 2007. Seamount benthos, In: Pitcher, T., Morato, T., Hart, P.J.B., Clark, M.R., Haggan, N., Santos, R.S. (Eds.), Seamounts: Ecology, 
Fisheries and Conservation. Blackwell Fisheries and Aquatic Resources Series. pp. 119-140.

Santos, R.S., Hawkins, S., Monteiro, L.R., Alves, M., Isidro, E.J., 1995. Marine research, resources and conservation in the Azores. Aquat. Cons. Mar. Fresh. Eco. 5 (4), 311354.

Sautya, S., Ingole, B., Ray, D., Stöhr, S., Samudrala, K., Raju, K.A.K., Mudholkar, A., 2011. Megafaunal Community Structure of Andaman Seamounts Including the Back-Arc Basin - A Quantitative Exploration from the Indian Ocean. PLoS ONE 6(1): e16162. doi:10.1371/journal.pone.0016162.

Shank, T.M., 2010. Seamounts. Deep-ocean laboratories of faunal connectivity, evolution, and endemism. Oceanography 23, 108-122.

Shirayama, Y., 1984. Vertical distribution of meiobenthos in the sediment profile in bathyal, abyssal and hadal deep sea systems of the western Pacific. Oceanol. Acta 7, 123-129.

Snelgrove, P.V.R, Butman, C.A., 1994. Animal sediment relationships revisited: Cause versus effect. Oceanogr. Mar. Biol. Annu. Rev. 32, 111-77.

Steyaert, M., Vanaverbeke, J., Vanreusel, A., Barranguet, C., Lucas, C., Vincx, M., 2003. The importance of fine-scale, vertical profiles in characterising nematode community structure. Estuar. Coast. Shelf Sci. 58, 353-366.

Tempera, F., Giacomello, E., Mitchell, N., Campos, A., Henriques, A., Bashmachnikov, I., Martins, A., Mendonça, A., Morato,T., Colaço, A., Porteiro,F., Catarino, D., Gonc-alves, J., Pinho,M., Isidro,E., Santos, R., Menezes, G., 2012. Mapping Condor seamount seafloor environment and associated biological assemblages (Azores, NE Atlantic). In: Harris, P., Baker, E. (Eds.), Seafloor Geomorphology as Benthic Habitat. GeoHAB 
Atlas of Seafloor Geomorphic Features and Benthic Habitats. Elsevier, USA, pp.807818.

Tracey, D.M., Rowden, A.A., Mackay, K.A., Compton, T., 2011. Habitat-forming cold-water corals show affinity for seamounts in the New Zealand region. Mar. Ecol. Prog. Ser. $430,1-22$.

Turnewitsch, R., Thomson, J., Lampitt R.S., Reyss, J.L., Chapman D.C. 2004. Evidence for a sedimentary fingerprint of an asymmetric flow field surrounding a short seamount. Ear. Plan. Sci. Let. 222 (3-4), 1023-1036.

Vanreusel, A., Fonseca, G., Danovaro, R., DaSilva, M., Esteves, A., Ferrero, T., Gad, G., Galtsova, V., Gambi, C., Genevois, V., Ingels, J., Ingole, B., Lampadariou, N., Merckx, B., Miljutin, D., Miljutina, M., Muthumbi, A., Netto, S., Portnova, D., Radziejewska, T., Raes, M., Tchesunov, A., Vanaverbeke, J., Van Gaever, S., Venekey, V., Bezerra, T.N., Flint, H., Copley, J., Pape, E., Zeppilli, D., Arbizu Martinez, P., Galeron, J., 2010. The contribution of deep-sea macrohabitat heterogeneity to global nematode diversity. Mar. Ecol. 31, $6-20$.

Vanreusel, A., Vincx, M., Schram, D., van Gansbeke, D., 1995. On the vertical distribution of the metazoan meiofauna in shelf-break and upper slope habitats of the NE Atlantic, Int. Rev. Gesamt. Hydrobiol. 80, 313-326.

Wentworth, C.K. 1922. A scale of grade and class terms for clastic sediments. J. Geol. 30, 377-392.

Wessel, P.,. Sandwell, D.T., Kim. S.S., 2010. The global seamount census. Oceanography 23(1), 24-33. 
White, M., Bashmachnikov, I., Aristegui, J., Martins, A., 2007. Physical processes and seamount productivity, in: Pitcher, T., Morato, T., Hart, P.J.B., Clark, M.R., Haggan, N., Santos, R.S. (Eds.), Seamounts: Ecology, Fisheries and Conservation. Blackwell Fisheries and Aquatic Resources Series, pp. 65-84.

Yesson, C., Clark, M.R., Taylor, M., Rogers, A.D., 2011. The global distribution of seamounts based on 30-second bathymetry data. Deep Sea Res. I 58(4), 442-453. 
Figure Captions

Fig. 1. Map of the study area (A) and sampling sites (B): summit (site 9); flank North (site 2); base North (site 3); flank South (site 4); base South (site 6); far field (site 8). Schematic representation of the sampling design (C): white cylinders represent sub-cores analyzed for meiofauna while the gray cylinder represents the core used for grain-size analyses.

Fig. 2 Grain size distribution of the investigated sampling sites. Grain size classes are: gravel $>2 \mathrm{~mm}$, sand $2 \mathrm{~mm}-0.063 \mathrm{um}$, silt 63-4 um, clay < 4 um (Wentworth, 1922).

Fig. 3 Total meiofaunal abundance in the Condor seamount and in the far field site. Data are means $( \pm \mathrm{SD})$.

Fig. 4 Meiofaunal biomass in the Condor seamount and in the far field site for Nematoda, Copepoda (including their nauplia), Tardigrada, Polychaeta, Loricifera, Acarina and others higher taxa (including Bivalvia, Ostracoda, Kinorhyncha, Cumacea, Amphipoda, Isopoda, Tanaidacea, Gastropoda and Echiura), as indicated. Data are means $( \pm \mathrm{SD})$.

Fig. 5 Vertical profiles of the meiofaunal abundance in the sediments (individuals X 10 cm-2), for Nematoda, Copepoda (including their nauplii), Tardigrada, Polychaeta, Loricifera, Acarina and others higher taxa (including Bivalvia, Ostracoda, Kinorhyncha, Cumacea, Amphipoda, Isopoda, Tanaidacea, Gastropoda, Echiura, Incertae sedis), as indicated. N.a. not available.

Fig. 6 Vertical profiles of the meiofaunal biomass in the sediments for Nematoda, Copepoda (including their nauplii), Tardigrada, Polychaeta, Loricifera, Acarina and 
others higher taxa (including Bivalvia, Ostracoda, Kinorhyncha, Cumacea, Amphipoda, Isopoda, Tanaidacea, Gastropoda, Echiura, Incertae sedis), as indicated. N.a. not available.

Fig. 7 Meiofauna community structures. (A) Relative contribution of Nematoda, Copepoda (including their nauplii), Tardigrada, Polychaeta, Loricifera, Acarina, Bivalvia, Ostracoda, Kinorhyncha, Cumacea, Amphipoda, Isopoda, Tanaidacea, Gastropoda, Echiura and Incertae sedis, as indicated. (B) Zoom on meiofauna community structure $(92-100 \%)$.

Fig. 8 Composite bathymetric section linking the six sampling sites $(8,3,2,9,4$, 6 from left to right) explaining the distribution of Ostracoda, Kinorhyncha, Cumacea, Amphipoda and Tardigrada.

Fig. 9 Higher meiofaunal taxa diversity. Alpha diversity expressed as the sum of the meiofaunal higher taxa at each sampling site. 'Total' shows the gamma (regional) diversity. 
Table 1. Location and water depth of the sampling sites.

\begin{tabular}{ccccc}
\hline Sampling site & Description & Latitude (N) & Longitude (W) & Depth (m) \\
\hline 9 & Summit & $38^{\circ} 32.94^{\prime}$ & $29^{\circ} 02.87^{\prime}$ & 206 \\
2 & Flank North & $38^{\circ} 35.26^{\prime}$ & $29^{\circ} 04.65^{\prime}$ & 1290 \\
4 & Flank South & $38^{\circ} 32.28^{\prime}$ & $29^{\circ} 06.07^{\prime}$ & 1006 \\
3 & Base North & $38^{\circ} 36.89^{\prime}$ & $29^{\circ} 04.59^{\prime}$ & 1687 \\
6 & Base South & $38^{\circ} 30.65^{\prime}$ & $29^{\circ} 08.20^{\prime}$ & 1719 \\
8 & Far Field & $38^{\circ} 33.30^{\prime}$ & $29^{\circ} 16.30^{\prime}$ & 1900 \\
\hline
\end{tabular}


Table 2. Grain size parameters of investigated samples obtained from GRADISTAT following Folk and Ward method (1957).

\begin{tabular}{|c|c|c|c|c|c|c|c|c|}
\hline Sampling site & Depth in the sediment $(\mathrm{cm})$ & Mean $(\mu \mathrm{m})$ & Sorting & Skewness & Kurtosis & $\mathrm{D}_{10}(\mu \mathrm{m})$ & $\mathrm{D}_{50}(\mu \mathrm{m})$ & $\mathrm{D}_{90}(\mu \mathrm{m})$ \\
\hline \multirow[t]{4}{*}{9 (Summit) } & $0-1$ & 1283.413 & 2.163 & -0.144 & 0.738 & 502.4 & 1118.0 & 4261.6 \\
\hline & $1-3$ & 1281.426 & 2.125 & -0.220 & 0.395 & 497.6 & 1114.2 & 5132.2 \\
\hline & $3-5$ & 1163.626 & 1.950 & -0.336 & 0.351 & 497.0 & 1116.2 & 6292.4 \\
\hline & $5-10$ & 957.785 & 2.529 & -0.197 & 0.596 & 267.3 & 1044.0 & 3793.8 \\
\hline \multirow[t]{5}{*}{2 (Flank N) } & $0-1$ & 80.770 & 5.016 & -0.375 & 1.069 & 6.327 & 122.2 & 437.9 \\
\hline & $1-3$ & 44.851 & 5.498 & -0.263 & 0.854 & 3.999 & 63.12 & 309.1 \\
\hline & $3-5$ & 44.502 & 6.252 & -0.235 & 0.787 & 3.492 & 62.39 & 365.1 \\
\hline & $5-10$ & 47.758 & 6.460 & -0.255 & 0.816 & 3.598 & 71.44 & 380.5 \\
\hline & $10-15$ & 40.657 & 5.869 & -0.226 & 0.796 & 3.467 & 55.07 & 317.7 \\
\hline \multirow[t]{5}{*}{4 (Flank S) } & $0-1$ & 51.812 & 6.317 & -0.259 & 0.825 & 3.857 & 74.99 & 422.5 \\
\hline & $1-3$ & 56.070 & 6.243 & -0.285 & 0.838 & 4.038 & 82.69 & 437.2 \\
\hline & $3-5$ & 56.601 & 5.533 & -0.328 & 0.906 & 4.476 & 84.67 & 371.7 \\
\hline & $5-10$ & 44.360 & 7.222 & -0.182 & 0.854 & 3.074 & 61.08 & 462.8 \\
\hline & $10-15$ & 67.061 & 7.989 & -0.236 & 0.833 & 3.538 & 95.80 & 808.4 \\
\hline \multirow[t]{5}{*}{3 (Base $N)$} & $0-1$ & 27.612 & 4.147 & -0.090 & 1.050 & 4.074 & 29.98 & 153.1 \\
\hline & $1-3$ & 25.825 & 4.372 & -0.134 & 0.955 & 3.497 & 29.84 & 146.1 \\
\hline & $3-5$ & 99.695 & 5.319 & 0.057 & 1.840 & 10.03 & 92.79 & 990.6 \\
\hline & $5-10$ & 26.130 & 5.720 & -0.024 & 0.769 & 2.773 & 26.74 & 239.9 \\
\hline & $10-15$ & 31.247 & 5.778 & -0.192 & 0.739 & 2.828 & 40.20 & 248.1 \\
\hline \multirow[t]{5}{*}{6 (Base $S)$} & $0-1$ & 25.257 & 5.840 & 0.066 & 0.794 & 2.859 & 23.09 & 269.9 \\
\hline & $1-3$ & 17.090 & 5.422 & 0.157 & 0.781 & 2.251 & 13.76 & 171.0 \\
\hline & $3-5$ & 20.342 & 5.945 & 0.114 & 0.793 & 2.351 & 17.47 & 235.3 \\
\hline & $5-10$ & 17.148 & 5.400 & 0.133 & 0.783 & 2.237 & 14.37 & 163.9 \\
\hline & $10-15$ & 13.013 & 5.256 & 0.252 & 0.808 & 1.898 & 9.258 & 132.4 \\
\hline \multirow[t]{2}{*}{8 (Far Field) } & $0-1$ & 79.865 & 13.602 & 0.223 & 0.968 & 3.560 & 45.80 & 2695.4 \\
\hline & $1-3$ & 13.741 & 43609 & 0.200 & 0.882 & 2.284 & 10.79 & 113.6 \\
\hline
\end{tabular}




\begin{tabular}{cccccccc}
$3-5$ & 15.411 & 4.600 & 0.128 & 0.853 & 2.444 & 13.22 & 118.5 \\
$5-10$ & 11.787 & 4.627 & 0.234 & 0.922 & 2.009 & 8.978 & 104.4 \\
$10-15$ & 11.209 & 4.620 & 0.246 & 0.962 & 1.943 & 8.509 & 101.4 \\
\hline
\end{tabular}


Table 3. Output of the one-way ANOVA carried out to test for differences of all of the variables investigated among all seamount and far field sites (d.f., degree of freedom; MS, mean square; F, F ANOVA statistic; P, probability level: ${ }^{* * *} \mathrm{P}<$ $0.001 ;{ }^{* *} \mathrm{P}<0.01 ;{ }^{*} \mathrm{P}<0.05$; n.s., not significant).

\begin{tabular}{lcccccc}
\hline Variables & d.f. & MS & F & P & & Output of the SNK test \\
\hline $\begin{array}{l}\text { Meiofaunal } \\
\text { abundance }\end{array}$ & 5 & 17.7965 & 3.45 & 0.0232 & $*$ & $\begin{array}{c}\text { Flank S> Far field } \\
\text { Base N > Base S } \\
>\text { others }\end{array}$ \\
$\begin{array}{l}\text { Meiofaunal biomass } \\
\begin{array}{l}\text { Richness of higher } \\
\text { taxa }\end{array}\end{array}$ & 5 & 5760.3 & 27.6 & 0.0000 & $* * *$ & \\
\hline
\end{tabular}


Table 4. Results of the ANOSIM and SIMPER analyses for differences in the meiofaunal community structures. The taxa responsible for the estimated differences are given. Only significant comparisons are reported.

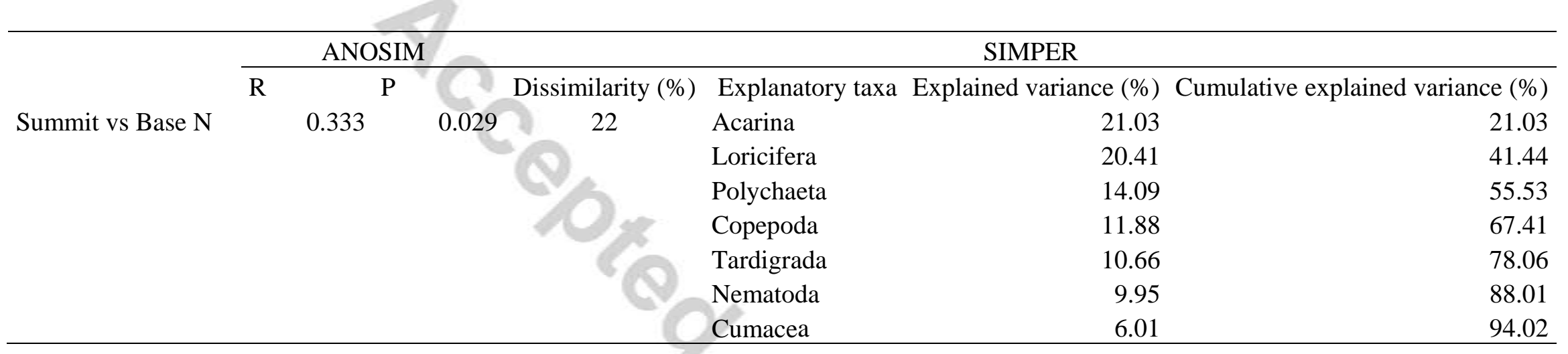


Table 5. Results of the DISTLM analysis showing relationships between predictor variables and meiofaunal community attributes $\left(^{*} \mathrm{p}<0.05\right.$; ${ }^{* *} \mathrm{p}<0.01$; ${ }^{* *} \mathrm{p}<$ $0.001)$.

\begin{tabular}{lrrrrc}
\hline Variables & \multicolumn{2}{c}{$F$} & \multicolumn{2}{c}{$\mathrm{R}^{2}$} \\
\hline Meiofaunal abundance & & & & & \\
Water depth & 65574 & 10.067 & 0.0026 & $* *$ & 30 \\
Phaeopigments & 16481 & 1.7918 & 0.2034 & ns & 8 \\
\% Silt & 7426.8 & 1.1549 & 0.2976 & ns & 3 \\
\% Clay & 7176.6 & 1.1074 & 0.305 & ns & 3 \\
& & & & & \\
Meiofaunal biomass & & & & & \\
PRT:CHO & 18223 & 27.699 & 0.0004 & $* * *$ & 56 \\
Phaeopigments & 7145 & 20.475 & 0.0002 & $* * *$ & 22 \\
Water depth & 3117 & 14.803 & 0.001 & $* *$ & 10 \\
\% Silt & 400.22 & 1.9953 & 0.1742 & ns & 1 \\
& & & & & \\
Meiofauna community structure & & & & \\
\% Gravel & 908.79 & 3.0222 & 0.007 & $* *$ & 12 \\
\% Clay & 655.59 & 2.0998 & 0.0522 & ns & 9 \\
Phaeopigments & 564.8 & 1.7855 & 0.103 & ns & 8 \\
Water depth & 554.97 & 1.7519 & 0.113 & ns & 7 \\
\% Silt & 525.94 & 1.6534 & 0.1402 & ns & 7 \\
\hline
\end{tabular}


Appendix I. Meiofaunal biomass $\left(\mu \mathrm{g} \mathrm{C} 10 \mathrm{~cm}^{-2}\right.$ ) in the Condor seamount and in the far field site for Nematoda, Copepoda (including their nauplia), Tardigrada, Polychaeta, Loricifera, Acarina and others higher taxa (including Bivalvia, Ostracoda, Kinorhyncha, Cumacea, Amphipoda, Isopoda, Tanaidacea, Gastropoda and Echiura), as indicated. Data are means. S.d. $=$ standard deviation.

\begin{tabular}{ccccccc}
\hline & 9 (Summit) & 2 (Flank N) & 4 (Flank S) & 3 (Base N) & 6 (Base S) & 8 (Far Field) \\
\hline Nematoda & 13.96 & 7.30 & 19.07 & 89.69 & 43.62 & 6.86 \\
Copepoda & 8.03 & 1.95 & 1.83 & 17.13 & 5.15 & 2.37 \\
Rotifera & 0.62 & 0.64 & 0.32 & 0.15 & 0.07 & 0.09 \\
Polychaeta & 2.34 & 0.59 & 1.51 & 1.06 & 0.78 & 1.27 \\
Tardigrada & 0.50 & 0.00 & 0.00 & 0.32 & 0.00 & 0.06 \\
Loricifera & 0.24 & 0.15 & 0.02 & 0.00 & 0.03 & 1.91 \\
Acarina & 1.46 & 0.64 & 0.44 & 3.10 & 1.21 & 0.73 \\
Others & 1.31 & 0.21 & 0.03 & 0.00 & 1.61 & 0.02 \\
\hline Total & 28.47 & 11.49 & 23.21 & 111.45 & 52.48 & 13.32 \\
\hline s.d. & 12.69 & 4.44 & 13.67 & 19.06 & 21.76 & 5.96 \\
\hline
\end{tabular}


Appendix II. Vertical profiles of the meiofaunal abundance in the sediments (individuals $\mathrm{X} 10 \mathrm{~cm}^{-2}$ ), for Nematoda, Copepoda (including their nauplii), Tardigrada, Polychaeta, Loricifera, Acarina and others higher taxa (including Bivalvia, Ostracoda, Kinorhyncha, Cumacea, Amphipoda, Isopoda, Tanaidacea, Gastropoda, Echiura, Incertae sedis), as indicated. Data are means. S.d. = standard deviation.

\begin{tabular}{cccccccccc}
\hline & 9 (Summit) & 9 (Summit) & 9 (Summit) & 9 (Summit) & 2 (Flank N) & 2 (Flank N) & 2 (Flank N) & 2 (Flank N) & 2 (Flank N) \\
\hline Layer $(\mathrm{cm})$ & $0-1$ & $1-3$ & $3-5$ & $5-10$ & $0-1$ & $1-3$ & $3-5$ & $5-10$ & $10-15$ \\
Nematoda & 57.09 & 56.35 & 56.84 & 48.02 & 130.10 & 42.14 & 6.62 & 3.68 & 0.98 \\
Copepoda & 5.64 & 7.11 & 3.68 & 7.35 & 12.25 & 1.47 & 0.25 & 0.25 & 0.00 \\
Tardigrada & 1.23 & 1.47 & 1.47 & 0.49 & 0.49 & 0.00 & 0.00 & 0.00 & 0.00 \\
Polychaeta & 0.25 & 0.25 & 0.00 & 0.49 & 0.49 & 0.00 & 0.00 & 0.00 & 0.00 \\
Loricifera & 0.00 & 0.25 & 0.00 & 0.00 & 1.47 & 0.25 & 0.00 & 0.00 & 0.00 \\
Acarina & 2.21 & 1.72 & 2.21 & 0.25 & 1.23 & 1.47 & 1.23 & 1.72 & 0.00 \\
Others & 0.98 & 0.49 & 0.00 & 0.49 & 0.25 & 0.25 & 0.00 & 0.00 & 0.00 \\
Total & 67.38 & 67.62 & 64.19 & 57.09 & 146.27 & 45.57 & 8.09 & 5.64 & 0.98 \\
s.d. & 21.13 & 24.08 & 40.46 & 11.85 & 42.13 & 20.41 & 5.90 & 2.17 & 1.39 \\
\hline
\end{tabular}


Appendix II. Continued.

\begin{tabular}{|c|c|c|c|c|c|c|c|c|c|c|}
\hline & 4 (Flank S) & 4 (Flank S) & 4 (Flank S) & 4 (Flank S) & 4 (Flank S) & $3($ Base N) & $3($ Base N) & $3($ Base $N)$ & $3($ Base $N)$ & $3($ Base $N)$ \\
\hline Layer $(\mathrm{cm})$ & $0-1$ & $1-3$ & $3-5$ & $5-10$ & $10-15$ & $0-1$ & $1-3$ & $3-5$ & $5-10$ & $10-15$ \\
\hline Copepoda & 14.46 & 3.43 & 1.47 & 0.00 & 1.23 & 9.80 & 2.70 & 0.25 & 0.00 & 0.25 \\
\hline Polychaeta & 1.23 & 0.49 & 0.00 & 0.25 & 0.00 & 1.23 & 0.00 & 0.00 & 0.00 & 0.00 \\
\hline Loricifera & 0.25 & 0.00 & 0.00 & 0.00 & 0.00 & 0.25 & 0.00 & 0.00 & 0.00 & 0.00 \\
\hline Acarina & 0.49 & 0.74 & 0.00 & 0.00 & 0.00 & 3.19 & 4.66 & 3.92 & 1.72 & 3.68 \\
\hline Total & 210.21 & 102.66 & 24.50 & 8.58 & 19.60 & 200.66 & 58.56 & 13.48 & 6.37 & 6.86 \\
\hline s.d. & 82.71 & 95.28 & 9.77 & 6.99 & 22.09 & 57.80 & 20.37 & 8.29 & 3.25 & 5.88 \\
\hline
\end{tabular}


Appendix II. Continued.

\begin{tabular}{|c|c|c|c|c|c|c|c|c|c|c|}
\hline Layer $(\mathrm{cm})$ & $\begin{array}{c}6 \text { (Base } \\
\mathrm{S}) \\
0-1\end{array}$ & $\begin{array}{c}6 \text { (Base } \\
\text { S) } \\
1-3\end{array}$ & $\begin{array}{c}6 \text { (Base } \\
\text { S) } \\
3-5\end{array}$ & $\begin{array}{c}6 \text { (Base } \\
\text { S) } \\
5-10\end{array}$ & $\begin{array}{c}6 \text { (Base } \\
\text { S) } \\
10-15\end{array}$ & $\begin{array}{c}8 \text { (Far } \\
\text { Field) } \\
0-1\end{array}$ & $\begin{array}{c}8 \text { (Far } \\
\text { Field) } \\
1-3\end{array}$ & $\begin{array}{c}8(\text { Far } \\
\text { Field) } \\
3-5\end{array}$ & $\begin{array}{c}8(\text { Far } \\
\text { Field }) \\
5-10\end{array}$ & $\begin{array}{l}8 \text { (Far } \\
\text { Field) } \\
10-15\end{array}$ \\
\hline Nematoda & 156.56 & 95.31 & 27.69 & 7.84 & 1.47 & 114.66 & 29.16 & 8.82 & 4.90 & 1.72 \\
\hline Tardigrada & 0.00 & 0.00 & 0.00 & 0.00 & 0.00 & 0.74 & 0.25 & 0.00 & 0.00 & 0.00 \\
\hline Polychaeta & 0.25 & 0.49 & 0.00 & 0.00 & 0.00 & 1.23 & 0.25 & 0.00 & 0.00 & 0.00 \\
\hline Loricifera & 3.19 & 0.00 & 0.00 & 0.00 & 0.00 & 1.23 & 0.25 & 1.23 & 0.25 & 0.00 \\
\hline Total & 181.06 & 98.49 & 29.16 & 11.52 & 1.96 & 128.38 & 32.34 & 10.29 & 5.88 & 2.21 \\
\hline s.d. & 49.16 & 42.96 & 22.45 & 10.57 & 1.39 & 28.64 & 12.73 & 4.27 & 2.12 & 2.17 \\
\hline
\end{tabular}


Appendix III. Vertical profiles of the meiofaunal biomass in the sediments $\left(\mu \mathrm{gC} X 10 \mathrm{~cm}^{-2}\right)$, for Nematoda, Copepoda (including their nauplii),

Tardigrada, Polychaeta, Loricifera, Acarina and others higher taxa (including Bivalvia, Ostracoda, Kinorhyncha, Cumacea, Amphipoda, Isopoda, Tanaidacea, Gastropoda, Echiura, Incertae sedis), as indicated. Data are means. S.d. = standard deviation.

\begin{tabular}{cccccccccc}
\hline & 9 & 9 & 9 & 9 & 2 & 2 & 2 & 2 & 2 \\
Layer $(\mathrm{cm})$ & $0-1$ & $1-3$ & $3-5$ & $5-10$ & $0-1$ & $1-3$ & $3-5$ & $5-10$ & $10-15$ \\
\hline Nematoda & 2.57 & 7.12 & 2.95 & 1.32 & 5.06 & 1.73 & 0.32 & 0.16 & 0.03 \\
Copepoda & 1.56 & 1.53 & 2.34 & 2.61 & 1.65 & 0.29 & 0.01 & 0.01 & 0.00 \\
Tardigrada & 0.24 & 0.18 & 0.07 & 0.02 & 0.00 & 0.00 & 0.00 & 0.00 & 0.00 \\
Polychaeta & 0.41 & 0.30 & 0.00 & 1.63 & 0.59 & 0.00 & 0.00 & 0.00 & 0.00 \\
Loricifera & 0.00 & 0.24 & 0.00 & 0.00 & 0.15 & 0.00 & 0.00 & 0.00 & 0.00 \\
Acarina & 1.09 & 0.18 & 0.19 & 0.01 & 0.21 & 0.17 & 0.17 & 0.09 & 0.00 \\
Others & 1.17 & 0.13 & 0.00 & 0.01 & 0.24 & 0.35 & 0.17 & 0.09 & 0.00 \\
Total & 7.03 & 9.68 & 5.54 & 5.60 & 7.91 & 2.54 & 0.66 & 0.35 & 0.03 \\
s.d. & 3.21 & 10.03 & 4.52 & 3.83 & 8.32 & 1.94 & 0.69 & 0.16 & 0.06 \\
\hline
\end{tabular}


Appendix III. Continued.

\begin{tabular}{|c|c|c|c|c|c|c|c|c|c|c|}
\hline & $\begin{array}{c}4 \\
(\text { Flank S) } \\
0-1\end{array}$ & $\begin{array}{c}4 \\
\text { (Flank S) } \\
1-3\end{array}$ & $\begin{array}{c}4 \\
(\text { Flank S) }\end{array}$ & $\begin{array}{c}4 \\
\text { (Flank S) }\end{array}$ & $\begin{array}{c}4 \\
\text { (Flank S) }\end{array}$ & $\begin{array}{c}3 \\
(\text { Base N) }\end{array}$ & $\begin{array}{c}3 \\
(\text { Base } N)\end{array}$ & $\begin{array}{c}3 \\
(\text { Base N) }\end{array}$ & $\begin{array}{c}3 \\
(\text { Base } N)\end{array}$ & $\begin{array}{c}3 \\
(\text { Base N)}\end{array}$ \\
\hline Layer $(\mathrm{cm})$ & $0-1$ & $1-3$ & $3-5$ & $5-10$ & $10-15$ & $0-1$ & $1-3$ & $3-5$ & $5-10$ & $10-15$ \\
\hline Nematoda & 10.82 & 5.66 & 1.28 & 0.37 & 0.93 & 12.55 & 58.00 & 10.55 & 5.27 & 3.33 \\
\hline Copepoda & 0.98 & 0.21 & 0.28 & 0.00 & 0.35 & 6.07 & 0.26 & 0.04 & 0.00 & 10.76 \\
\hline Tardigrada & 0.00 & 0.00 & 0.00 & 0.00 & 0.00 & 0.32 & 0.00 & 0.00 & 0.00 & 0.00 \\
\hline Polychaeta & 0.95 & 0.38 & 0.00 & 0.19 & 0.00 & 1.06 & 0.00 & 0.00 & 0.00 & 0.00 \\
\hline Loricifera & 0.02 & 0.00 & 0.00 & 0.00 & 0.00 & 0.00 & 0.00 & 0.00 & 0.00 & 0.00 \\
\hline Acarina & 0.06 & 0.38 & 0.00 & 0.00 & 0.00 & 0.88 & 1.04 & 0.40 & 0.31 & 0.47 \\
\hline Others & 0.01 & 0.01 & 0.00 & 0.00 & 0.00 & 0.00 & 0.00 & 0.00 & 0.00 & 0.00 \\
\hline Total & 12.84 & 6.63 & 1.57 & 0.56 & 1.29 & 20.88 & 59.30 & 10.98 & 5.58 & 0.05 \\
\hline s.d. & 13.45 & 5.98 & 1.34 & 0.33 & 1.92 & 5.79 & 25.52 & 5.64 & 3.49 & 21.62 \\
\hline
\end{tabular}


Appendix III. Continued.

\begin{tabular}{|c|c|c|c|c|c|c|c|c|c|c|}
\hline Layer $(\mathrm{cm})$ & $\begin{array}{c}6 \text { (Base } \\
\text { S) }\end{array}$ & $\begin{array}{l}6 \text { (Base } \\
\text { S) }\end{array}$ & $\begin{array}{c}6 \text { (Base } \\
\mathrm{S})\end{array}$ & $\begin{array}{c}6 \text { (Base } \\
\mathrm{S})\end{array}$ & $\begin{array}{c}6 \text { (Base } \\
\mathrm{S})\end{array}$ & $\begin{array}{l}8(\text { Far } \\
\text { Field })\end{array}$ & $\begin{array}{l}8(\text { Far } \\
\text { Field })\end{array}$ & $\begin{array}{l}8(\text { Far } \\
\text { Field })\end{array}$ & $\begin{array}{l}8(\text { Far } \\
\text { Field })\end{array}$ & $\begin{array}{l}8(\text { Far } \\
\text { Field })\end{array}$ \\
\hline Nematoda & 19.12 & 15.68 & 6.13 & 2.47 & 0.23 & 3.39 & 2.30 & 0.42 & 0.73 & 0.03 \\
\hline Copepoda & 4.90 & 0.09 & 0.16 & 0.00 & 0.00 & 1.67 & 0.43 & 0.00 & 0.00 & 0.35 \\
\hline Tardigrada & 0.00 & 0.00 & 0.00 & 0.00 & 0.00 & 0.06 & 0.01 & 0.00 & 0.00 & 0.00 \\
\hline Acarina & 0.47 & 0.09 & 0.17 & 0.40 & 0.07 & 0.47 & 0.10 & 0.02 & 0.14 & 0.00 \\
\hline Others & 1.17 & 0.01 & 0.00 & 0.43 & 0.00 & 0.00 & 0.02 & 0.00 & 0.00 & 0.00 \\
\hline Total & 25.88 & 16.46 & 6.46 & 3.30 & 0.30 & 8.36 & 3.23 & 0.47 & 0.88 & 0.39 \\
\hline s.d. & 4.13 & 9.12 & 8.68 & 5.00 & 0.37 & 5.60 & 1.79 & 0.21 & 1.36 & 0.60 \\
\hline
\end{tabular}


Fig 1

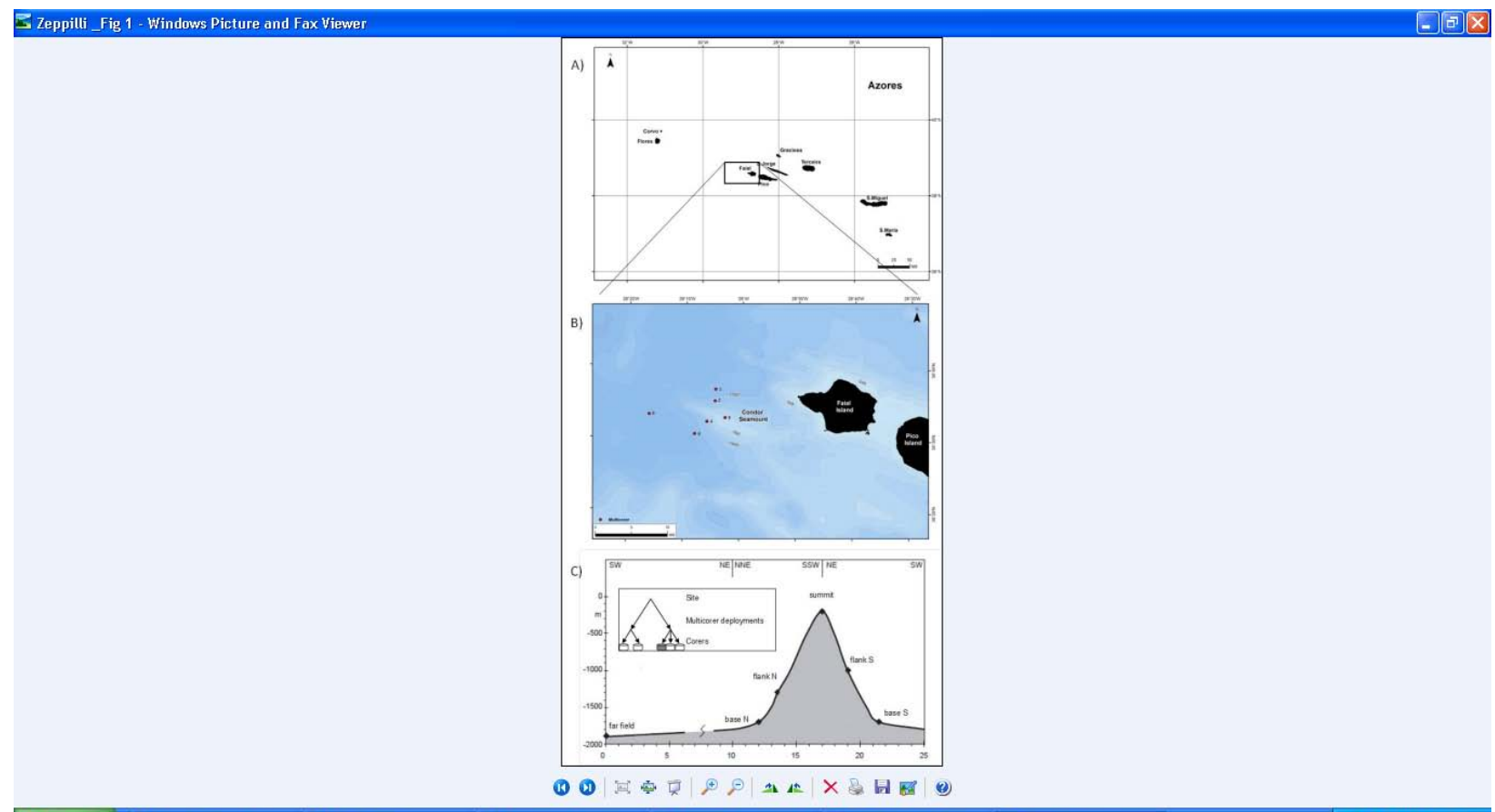


Fig 2

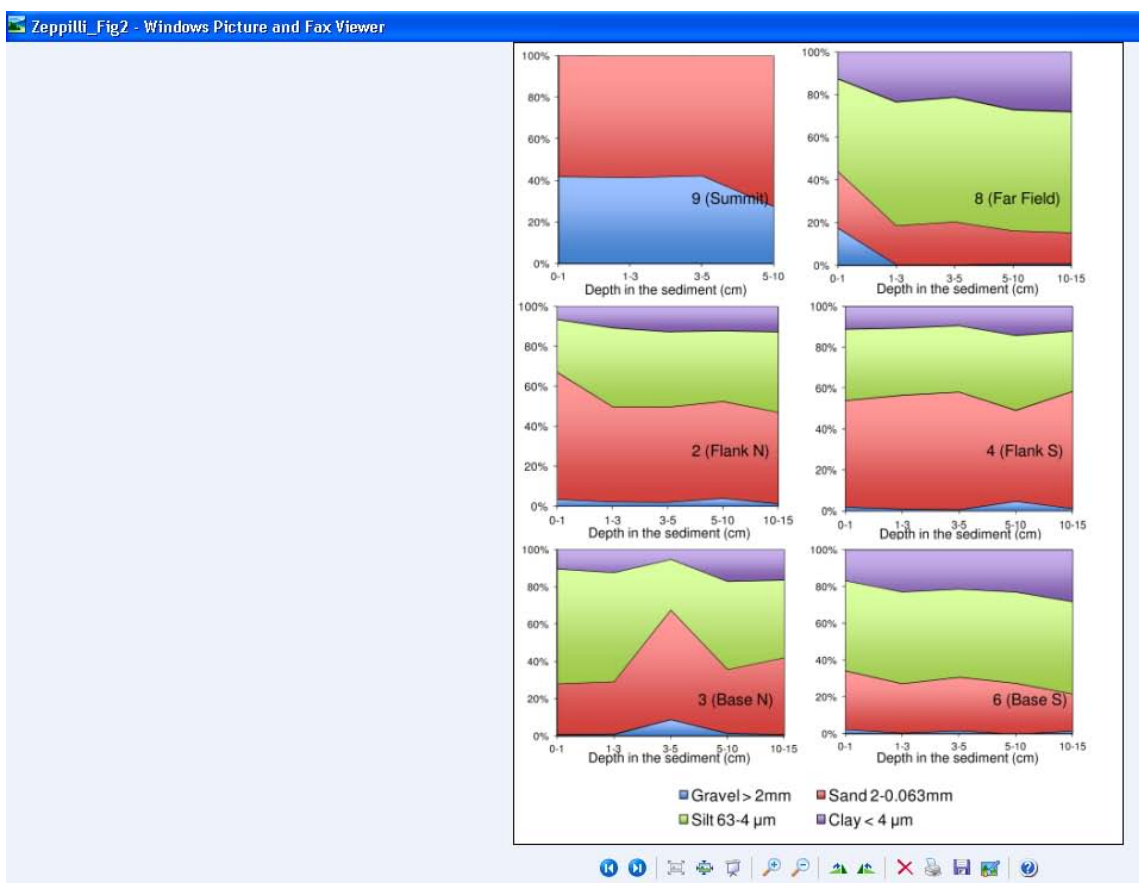


Fig 3

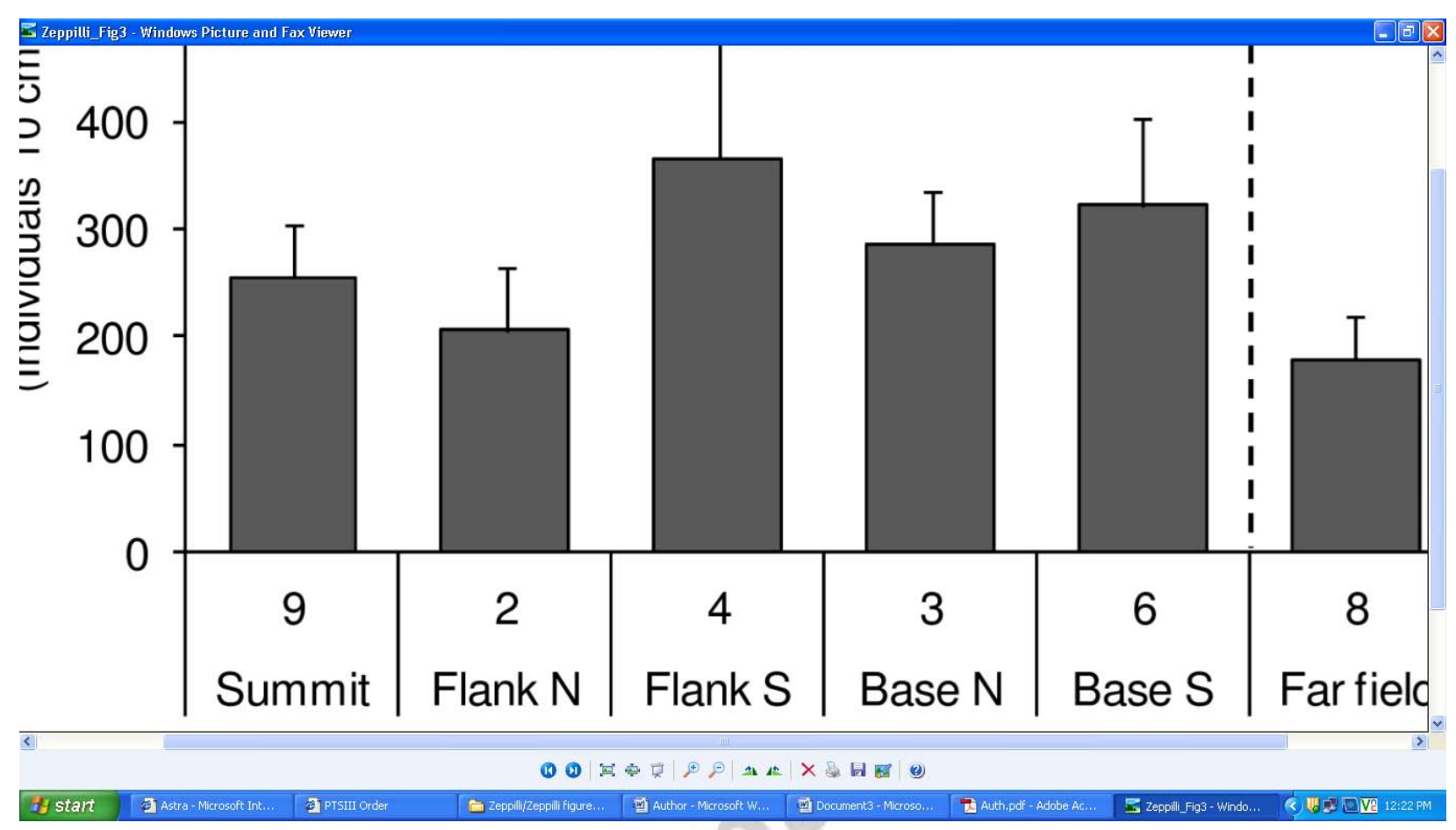


Fig 4

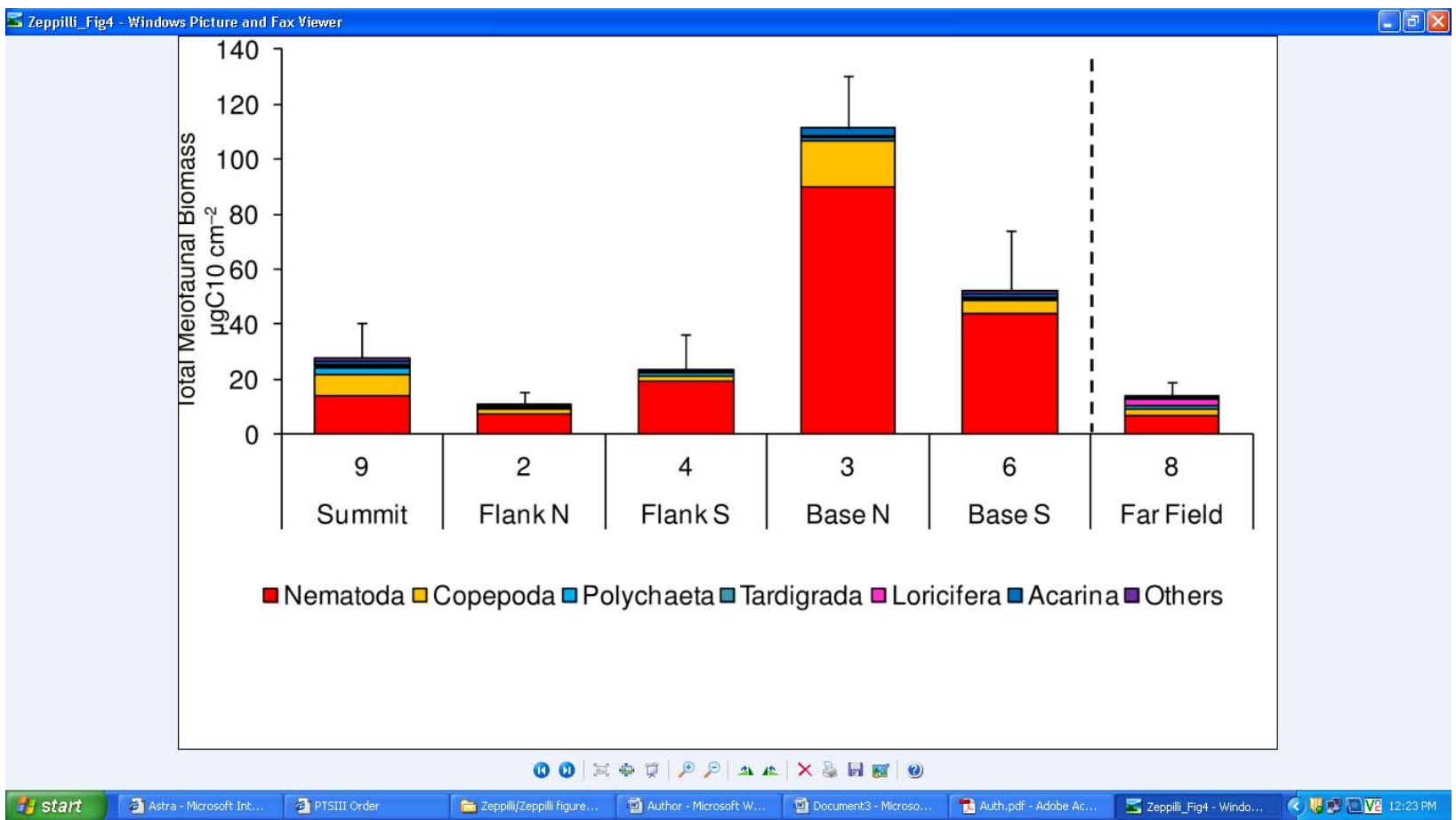


Fig 5

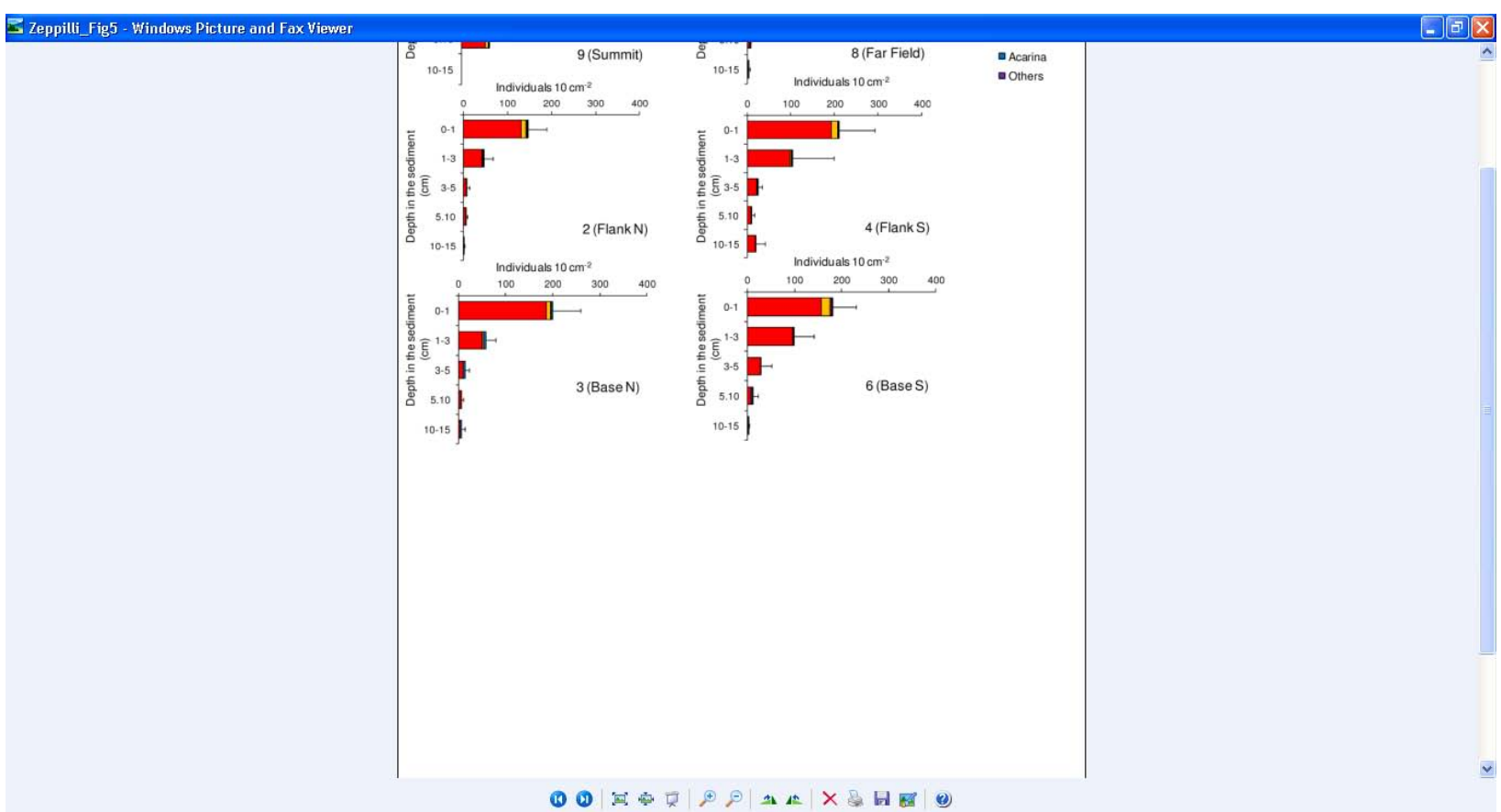

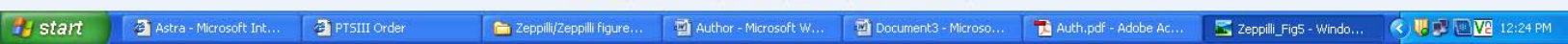


Fig 6

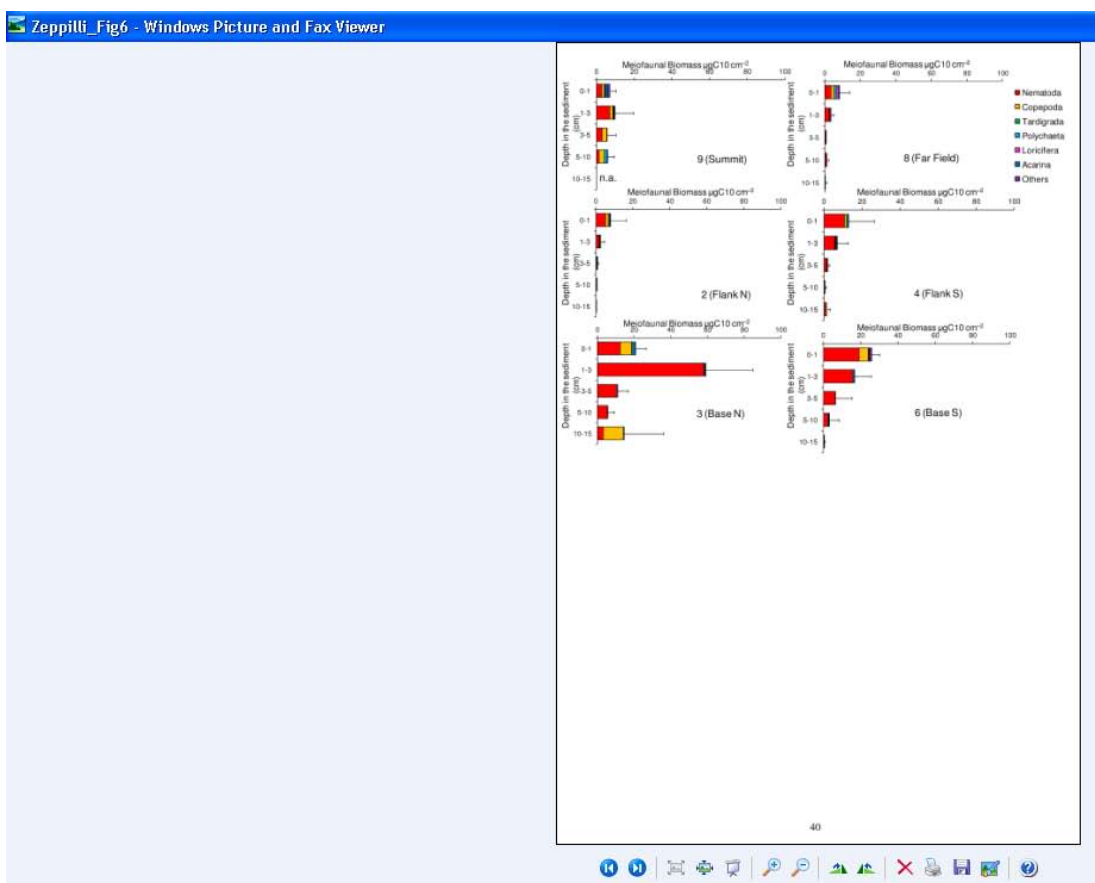


Fig 7

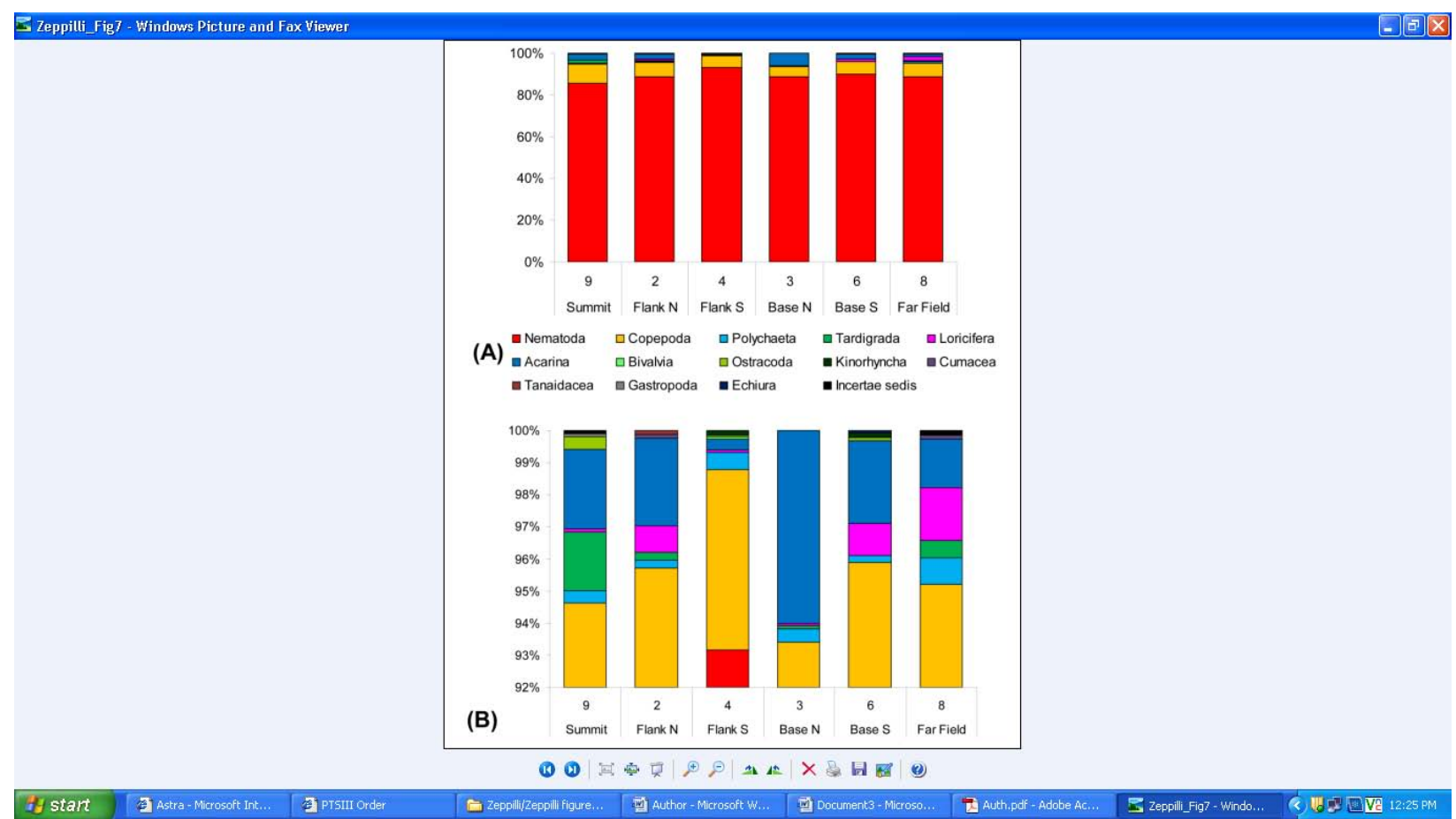


Fig 8

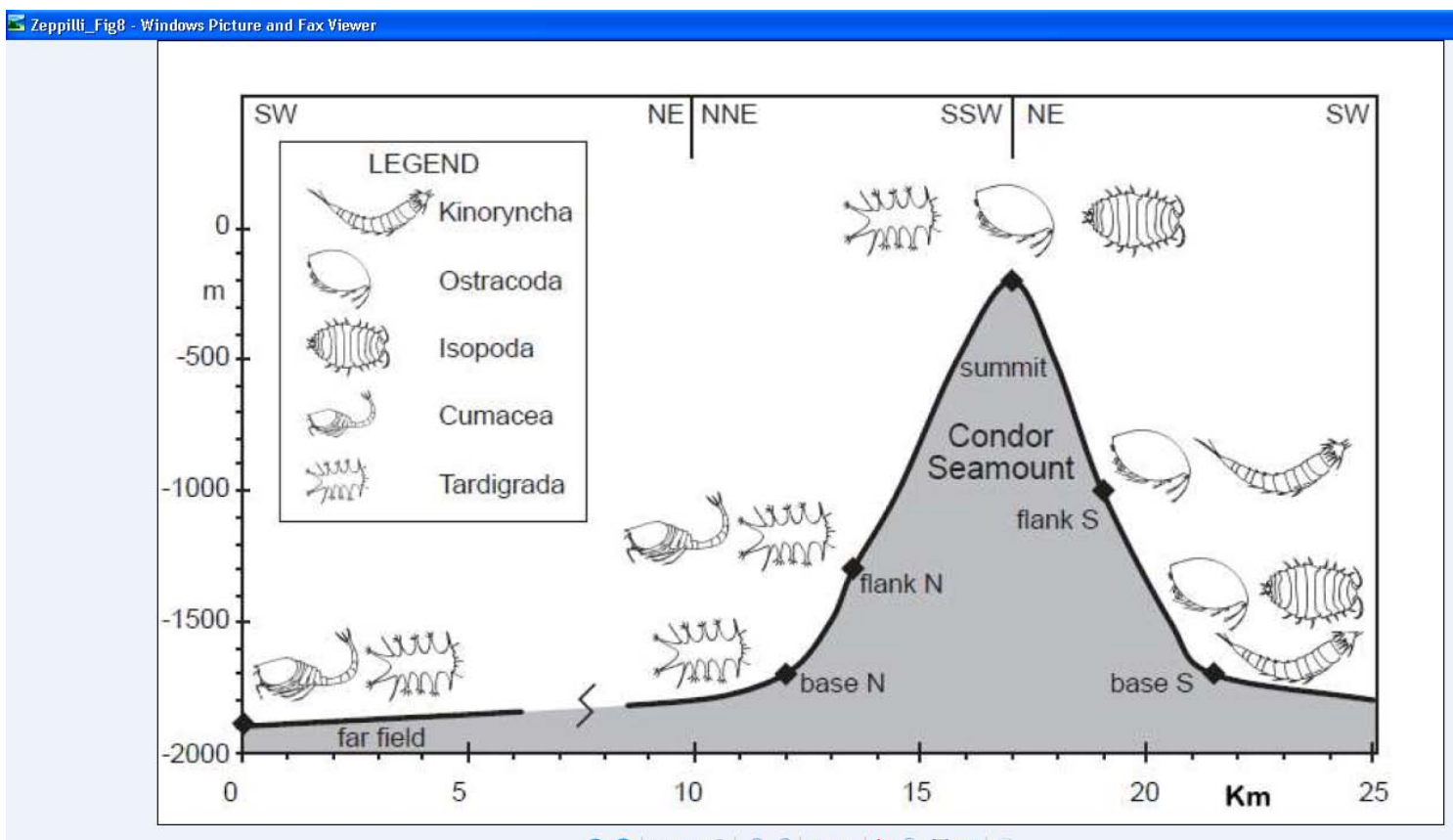


Fig 9

Zeppilli_Fig9 - Windows Picture and Fax Viewer

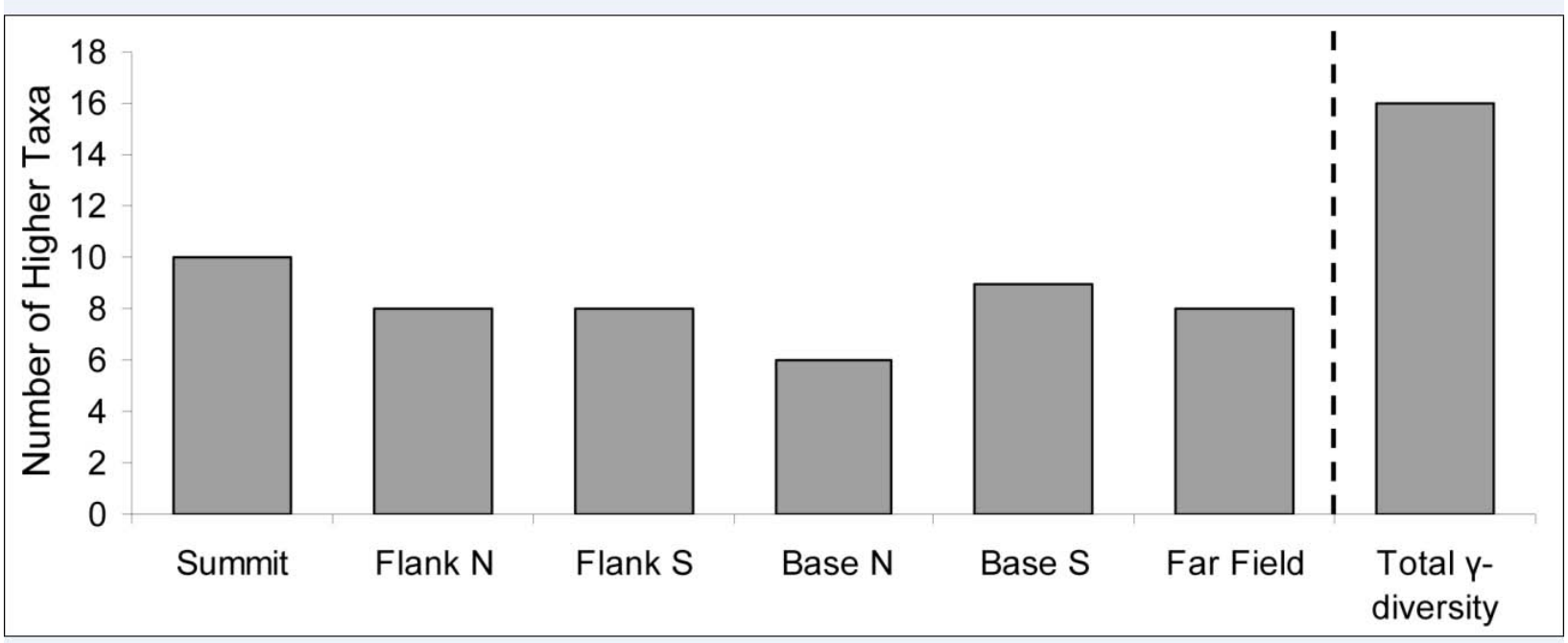

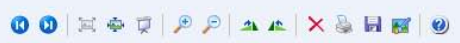

